\title{
WestVirginiaUniversity
}

THE RESEARCH REPOSITORY @ WVU

Graduate Theses, Dissertations, and Problem Reports

2012

\section{Investor Relations: A study of entry-level expertise and education}

Deepa Fadnis

West Virginia University

Follow this and additional works at: https://researchrepository.wvu.edu/etd

\section{Recommended Citation}

Fadnis, Deepa, "Investor Relations: A study of entry-level expertise and education" (2012). Graduate Theses, Dissertations, and Problem Reports. 3351.

https://researchrepository.wvu.edu/etd/3351

This Thesis is protected by copyright and/or related rights. It has been brought to you by the The Research Repository @ WVU with permission from the rights-holder(s). You are free to use this Thesis in any way that is permitted by the copyright and related rights legislation that applies to your use. For other uses you must obtain permission from the rights-holder(s) directly, unless additional rights are indicated by a Creative Commons license in the record and/ or on the work itself. This Thesis has been accepted for inclusion in WVU Graduate Theses, Dissertations, and Problem Reports collection by an authorized administrator of The Research Repository @ WVU. For more information, please contact researchrepository@mail.wvu.edu. 


\title{
Investor Relations: A study of entry-level expertise and education
}

\author{
Deepa Fadnis \\ Thesis submitted to the \\ Perley Isaac Reed School of Journalism \\ at West Virginia University \\ in partial fulfillment of the requirements \\ for the degree of \\ Master of Science \\ in \\ Journalism
}

\author{
Diana Martinelli, Ph. D., Chair \\ Ivan Pinnell, Ph. D. \\ Charles R. Harman, Adjunct \\ Melissa Kivett, Sr. VP - Investor Relations, Assurant, Inc. \\ School of Journalism \\ Morgantown, West Virginia \\ 2012
}

\footnotetext{
Keywords: Investor Relations, Entry-level, Tasks, Communications, Public Relations, Finance Copyright 2012 Deepa Fadnis
} 


\title{
Abstract
}

\section{Investor Relations: A study of entry-level expertise and education}

\author{
Deepa Fadnis
}

Today, Investor Relations (IR) is an integral part of the working of every publicly listed corporation. In the light of the growth and development in the field of IR, this study attempts to gauge the entry-level standards in education and expertise set by the industry. Using responses to online surveys administered to experienced IR practitioners, the study provides answers to research questions. These research questions are based on the tasks performed, skills required and preferred academic coursework in the field of IR. Further, these questions also explore the position and importance of communications in the IR's unit of hierarchy of tasks. The findings of this research study suggest that although skills and academic coursework in communications are important, they are considered secondary to financial understanding and business acumen. Backed by the systems theory, this study suggests constructing an integrated framework of academic coursework and proficiencies in communications and finance for the field of IR. 


\section{Acknowledgements}

Two years back, when I walked in to the PR 522 class, I had no idea I would begin working on my thesis that very day. A semester long project in which I explored the basics of Investor Relations, laid the foundation for my graduate thesis

To be honest, my graduate thesis would not have shaped the way it did without, Dr. Diana Martinelli. I remember the first time I spoke to you about my thesis, your eyes lit up. Your enthusiasm through this process has kept me going. I want to thank you for agreeing to chair my committee, in spite of being on a sabbatical, guiding me through every step in this project. You have on more than one occasion, absolutely gone out of your way to smoothen things out for me and I am grateful to you for doing that. Your unique nurturing ways have helped me push myself to new levels of excellence. You make working hard worth it! Thank you for always being there. Your mentoring has meant the world to me.

I would also like to thank, Dr. Steve Urbanski, without whom I would have been completely lost in my MSJ program. If you hadn't pushed our class to start thinking about possible ideas for our thesis, I would have never graduated on time. Your presence puts me to ease and I know no matter what doubts I have, you'd always take the time to clear them. Your patience and perseverance is inspiring. Thank you for everything.

I would like to thank, Dr. Ivan Pinnell and Professor. Charles Harman for agreeing to be a part of my committee and for their valuable time. The study has borrowed a lot from your experience and guidance. I really appreciate your presence on my thesis committee.

I am grateful to Todd Tauber, for taking interest in my thesis and for introducing me to Melissa Kivett. Melissa, your experience and expertise in the field of Investor Relations have been most valuable to the project. Even with one of the busiest schedules, you made time to guide and contribute to this study. I cannot thank you enough for instantly agreeing to be a part of my thesis committee and for your recommendations.

I am thankful to my parents, Dr. Rajan Fadnis and Mrs. Anita Fadnis, for absolutely everything. You believe in me, hold me when I fall and help me get back on my feet each time. And by now, you've listened to hours of endless ranting about my thesis and you still want to talk to me everyday. That is something.

Finally, I would like to thank my classmates, Kristen Wishon and Catherine Lovell for sharing these two wonderful years of school with me. You both have immensely helped me come this far. Thank you for all the laughs and giggles and for all the words of encouragement. 


\section{Table of Contents}

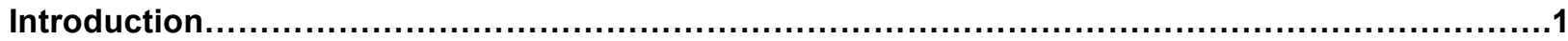

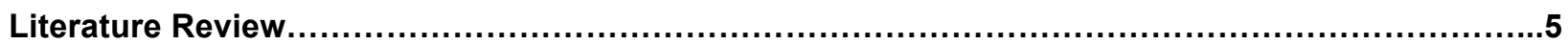

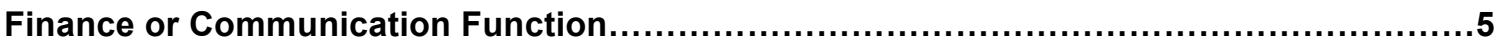

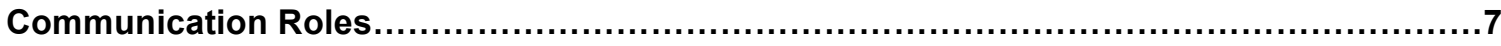

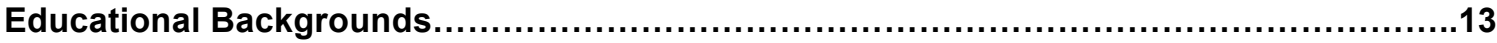

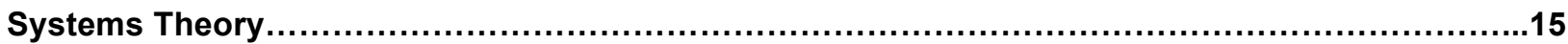

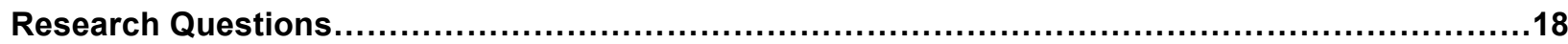

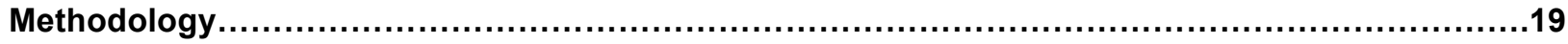

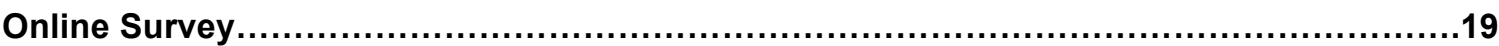

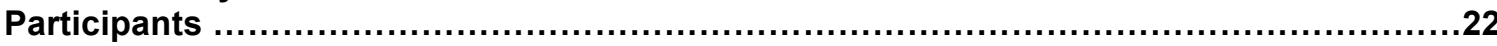

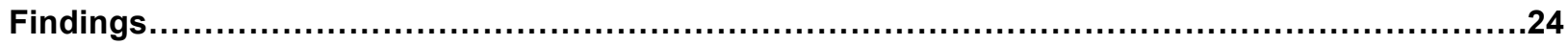

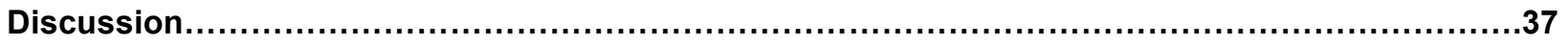

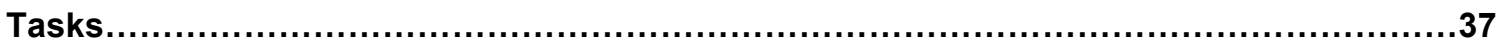

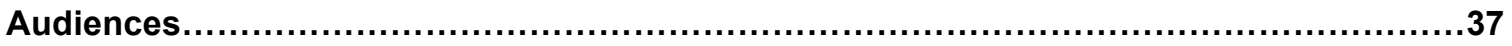

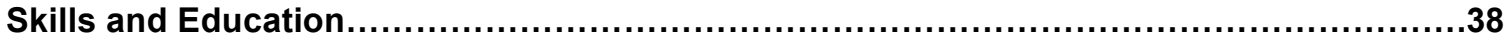

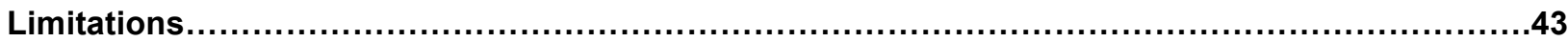

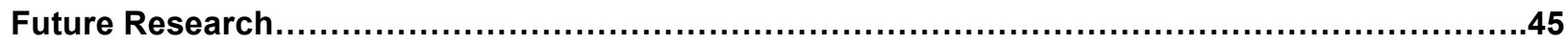

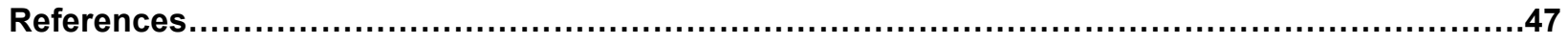

Appendix A: Institutional Review Board approval and Cover Letter.........................................52

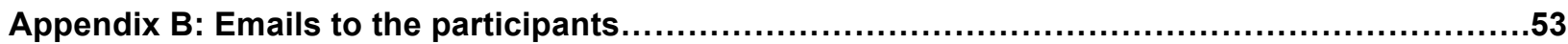

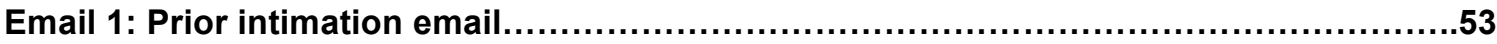

Email 2: Formal protocol consent cover letter and the link to the survey...................54

Email 3: Reminder 1 sent one week after the formal letter was distributed..................55

Email 4: Reminder 2 sent two weeks after the formal letter was distributed..................56

Email 5: Reminder 3 sent three weeks after the formal letter was distributed.................57

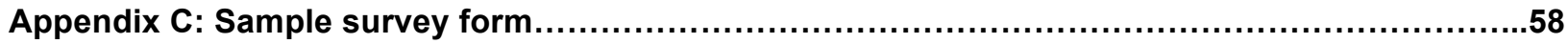

Appendix D: List of tasks performed and preferred academic coursework $\ldots \ldots \ldots \ldots \ldots \ldots \ldots \ldots \ldots \ldots 1$ 


\section{Introduction}

Although small in number, publicly owned companies are the core of the capitalistic economies in the United States and elsewhere. At the end of 2010, the World Bank reported a total of four thousand listed companies and estimated the market capitalization of these companies to be more than 17 trillion dollars. According to Kelly, Laskin and Rosenstein (2010), "The importance of investor relations is tied to the principle that the relationship between investor publics and corporate management affects a company's bottom line" (p.184). Indeed, Wall Street has numerous information sources to help investors, but all those numbers don't mean much if the investor has not heard about the company or does not trust the people who run it. The recent Wall Street protests are excellent examples of decreasing trust levels in the capitalist society, the government and financial institutions (Sorkin, 2011). Dorel, Marian, Elena, Cristian \& Dorel (2010) are of the opinion that the globalization, internationalization and continuous development of business lead to companies' adapting to the new conditions imposed by the markets. As such companies must now, more than ever include, as a component part, the management of their economical-financial communications.

The National Investor Relations Institute (NIRI) is a professional association of corporate officers and investor relations consultants responsible for communication among corporate management, shareholders, securities analysts and other financial community constituents. It is also the largest professional investor relations association in the world. NIRI has more than 3,500 members representing 2,000 publicly held companies and $\$ 5.4$ trillion in stock market capitalization (NIRI, 2011). 
Laskin (2009) notes that NIRI defines investor relations as a strategic management responsibility that integrates finance, communication, marketing and securities law compliance to enable the most effective two-way communication between a company, the financial community and other constituencies, which ultimately contributes to a company's securities achieving fair valuation (p. 210).

While this definition is widely accepted today, Farragher, Kleiman and Bazaz (1994) suggest that investor relations specialists view their work as providing investors with timely, accurate and complete information about a corporation's business fundamentals and future prospects. They claim that the better a corporation is at communicating timely, accurate and complete information, the more confident are security analysts and investors about their ability to accurately forecast earnings per share (p. 404). In 1976, seven years after NIRI's founding, Public Relations Society of America (PRSA) established an "Investor Relations Section" for its members, renaming it the "Financial Communications Section" in 1992 (PRSA, n.d.). Further Laskin (2009) found that a public relations professional organization defines investor relations as one of public relations' functions. The Body of Knowledge Task Force of PRSA (1988) included investor relations as one of the seven sub-functions of public relations, along with media, internal employees management, consumer, community, government, and fundraising/donor relations (p. 211).

From the outset, NIRI separated their members from public relations practioners in what NIRI directors referred to as "separating the wheat from the chaff" (Morrill, 1995). One of the directors stated in the institute's first progress report, "Our aim is to separate ourselves from the so-called financial public relations consultants, who operate on the fringe of stock touting, and who are fouling the nest" (Morrill, 1995). 
Nonetheless, the issue of communicating with investors and shareholders did not garner much attention from executives until much later (NIRI, 1985, 1989). David Silver (2004) elucidates "investor relations emerged into its own in the 1960s, often associated with the so-called dog and pony shows for sell-side analysts and retail investors, usually held at the offices of securities brokerages" (p. 70). The major growth, however, happened in the latter half of the 1980s. Indeed, NIRI (1985) conducted research, which indicated that only $16 \%$ of the Fortune 500 companies had investor relations departments in 1985. However, a similar study in 1989 showed that $56 \%$ of these organizations claimed to have an investor relations department (NIRI, 1989). A study by Rao and Sivakumar (1999), who analyzed the appearance of investor relations departments, revealed that organizations developed their investor relations activities in the late 1980s and early 1990s under pressure from social movement activists and financial analysts (p. 27).

NIRI and PRSA's professional interest section have coexisted over the last 32 years, with some degree of understanding that members of the two groups differ in their expertise and responsibilities. NIRI adopted a practice to conduct background checks on consultants applying for membership "to keep the chaff out" (Morrill, 1995). NIRI members are considered more finance oriented than members of PRSA's professional interest section, who are oriented to communications/public relations. Simplistically, the former is responsible for communication with investors and stock analysts, whereas the latter deals with the financial media. The two groups also differ in composition of their membership. NIRI's goal from its founding has been to maintain a membership that is predominantly corporate practitioners (about $80 \%$ ) (Morrill, 1995), whereas PRSA's section traditionally attracts half or more of its members from the consulting firms. In favor of this, Silver (2005) argued that public relations and investor relations are not the same: they inhabit radically dissimilar environments and with different audiences and skill sets (p. 14). Yet the thrust of Silver's article was that the current environment in which 
publicly owned corporations operate demands the convergence of investor relations and financial public relations.

With high profile public protest and financial scandals like Enron and WorldCom, trust in corporate America has been undermined, so companies need to reach out to the country's 84 million investors to work towards improving trust (Murray, 2004). According to Allen, the collapse of the energy giant Enron was one of the most shocking failures in US corporate history. At the same time, Enron's bankruptcy was a wake-up call for corporate America that made shareholders scrutinize closely the companies they invest in: "In the post Enron era, investor relations vaults to the top of the corporate agenda, as companies must begin to rebuild investor confidence" (Allen, 2002, p. 206). Today, trust is no longer assumed and, thus, investor relations profession is recognized as an activity capable of creating "a competitive advantage" (pp. 206-207). To work towards restoring trust, the 2002 Sarbanes-Oxley Act (SOX) was passed. Designed to improve investor confidence, SOX makes CEOs and CFOs of public companies legally accountable for the veracity and integrity of their financial statements (Goodman, 2004). NIRI (2011) defines SOX as a far-reaching piece of legislation that has multiple components addressing a broad array of corporate governance issues and standards such as internal controls, board responsibilities and auditor independence.

As a result, today, the significance of investor relations is emphasized as the investor relations profession not only seeks to increase stock valuations in the market but also to regain the trust of people which has eroded in recent years (Tonello, 2006). In the backdrop of this increased corporate responsibility and accountability, this study will help to inform prospective students, faculty and administrators about this increasingly important field and the skills and knowledge most useful to enter it. 


\section{Literature Review}

\section{Finance and/or communication function}

The price of a company's share indicates its financial health and is an important incentive for people to invest in the company. That price results both from the company's actual performance and from perceptions of its future performance; those perceptions can be considerably shaped by what the management conveys through their investor relations activities. These activities can encourage investors and make a big difference when the management needs shareholder's approval to make important board decisions. According to MacGregor and Campbell (2006), "Your company is doing a good job on investor relations when the right investors own your shares for the right reasons, and the price of your shares appropriately reflects your company's prospects relative to its peers" (p. 60).

But shareholders are not the only audiences to whom investor relations practitioners cater. Other audiences range from the media to regulators to advisory services to analysts and ultimately to the investor - individual as well as institutional. Individual investors are individual owners of a financial asset who typically invest on their own behalf. According to Michaelson and Gilfeather (2003), more traditional individual investors are those who make self-directed investments, albeit often with the input and advice of analysts and registered representatives. Few public companies have specific campaigns to market their stocks to these individual investors. However, individual investors are attractive to some companies because they tend to buy stocks and hold them. Institutions are much quicker to sell stocks than individuals (day traders excepted). In contrast, institutional investors own most of the stock in major public companies and, therefore, are prime targets for investor relations communications, for both compliance and marketing reasons. But on the other hand, Haas (1991) suggested that the prime communications target, "the people who matter most," are now recognized as not just the 
institutional investors who account for $85 \%$ or so of Big Board trades, but individual investors, who account for little more than $15 \%$ of trading volume but actually own about $56 \%$ of common shares on the Big Board (p. 17).

According to Michaelson and Gilfeather (2003), the laws and rules that govern the securities industry in the United States derive from a simple and straightforward concept: all investors, whether large institutions or private individuals, should have access to certain basic facts about an investment prior to buying it. To achieve this, the Securities and Exchange Commission (SEC) requires public companies to disclose meaningful financial and other information to the public, which provides a common pool of knowledge for all investors to use to judge for themselves if a company's securities are a good investment.

They also define the types of media to which investor relations officers need to effectively communicate. According to Haas (1991), aggressive IR professionals — including nearly all the top PR firms and hundreds of corporate IR departments-are increasing their communications success by increasing the number of media they pitch to. These media are foreign newspapers and magazines in the world's financial capitals, American newspapers and magazines not on the old laundry lists of "financial media" and TV and radio in the U.S. and abroad.

Increasingly, online communication and in particular social media, is ideally suited to helping investor relations officers fulfill this mission. Social media excels in offering two way communication channels and provides investor relations officers with a promising new platform for full disclosure, transparency and dialogue. A study conducted by Hogan (2009), shows that institutional investors and analysts are ideally suited for social media. They are highly educated, affluent and very mobile. Blackberry or iPhone use is almost universal among this crowd. Studies confirm the interest of professional investors in social media. Joyce (2009) also believes 
that social media will become increasingly important in helping investors make investment decisions

Luoma-aho (n.d) is of the opinion that stakeholder relations are no longer what they used to be, namely in the reputation society we have entered into, which is a time of strong emotions. She believes that organizations have become targets of these emotions, both love and hate. New technology has catalyzed this by enabling quicker information sharing, and the various social media help and support community formation around issues. Stakeholders today have more information, skills and easy access to show their emotions and collect supporters for their ideas, both good and bad. These changes have also resulted in some stakeholder groups becoming more demanding and powerful, and maintaining stakeholder relations is taking larger amounts of organizational effort and time than before.

\section{Communication Roles}

Laskin (2009) argues that investor relations is a practice on the borderline of business and communications, and synergy between these two areas is essential. A study conducted by Petersen \& Martin (1996) found that in $57 \%$ of cases, chief financial officers (CFOs) supervise the investor relations activities related to the disclosure of information affecting the stock price, while communication/public relations officers are in charge of such activities in $13 \%$ of all cases. The study also found that the investor relations activities are largely conducted by the financial affairs department- $63 \%$ of the total-while public relations departments were responsible for the investor relations activities in $12 \%$ of the total cases. They concluded that the investor relations function is seldom managed by communication/public relations practitioners, not because the activities are essentially different but because CEOs "do not perceive investor relations to be part of the public relations function" (Petersen and Martin 1996, p. 173). Argenti 
(2002) recognizes that although, traditionally, investor relations practice was managed by finance departments, "the focus today has moved away from just the numbers to the way the numbers are actually communicated to various constituencies" (p. 46).

In addition, as public relations is more than submitting a press release to a newspaper, investor relations should be recognized as more than providing financial documents to the shareholders. Tuominen (1997), studying investor relations practices in the Finnish stock market, proclaimed that "success in investor relations requires the companies to extend the scope of investor relations from a mere publication of obligatory annual and interim reports to more frequent, extensive, proactive and diversified two way interaction and communication" (p. 46). According to MacGregor and Campbell (2006), investor relations, properly managed, is not just a megaphone for outbound messaging. It is also a microphone for incoming messaging, and it's important that the essence of that incoming messaging makes its way to the boardroom. This liaison role is a foundation of modern public relations practice as well. The exchange occurs through the building of mutually beneficial relationships based on a balanced flow of information from and to the organization and its key publics. Clearly, for the practice of public relations to ensure openness, it requires the support and involvement of the management (Mckee \& Lamb, 2005).

Petersen \& Martin's study advances an important claim—the investor relations function is not sufficiently integrated into the strategic communication activities of the organizations, but instead is managed predominantly by the financial departments. The authors summarize that investor relations is "most frequently treated as a financial function, both in terms of who is in charge, and the qualifications for the job" (1996, p. 204). 
Laskin (2009) showed that about $65 \%$ of investor relations executives work in dedicated investor relations departments in companies. The other $35 \%$ did not have a dedicated investor relations departments; instead, for $27 \%$, the investor relations function at their organization was handled by the finance department, and for $8 \%$, the investor relations function was managed by the communications/public relations department (p. 217). MacGregor and Campbell (2006) note that investor relations at a large corporation might be a ten-person department headed by a very senior executive skilled in both finance and communications, while at a small corporation, it could be a part-time responsibility for an assistant treasurer.

The 1997 Corporate Communications Benchmark survey conducted by Edelman in conjunction with Northwestern University and Opinion Research Corp, surveyed senior communications officials at more than 700 public companies about their perception of the investor relations practice. The results showed that investor relations departments receive the top marks from their audiences for being accessible, informed and empowered and for providing access to responsive senior management (Greco, 1998).

However, Laskin (2007) points out that investor relations officers (IROs) say that one of the biggest challenges of their work is proving to management that investor relations contributes value to their organization (as cited in Laskin, 2005). Indeed, one might consider it obvious that investor relations is good for an organization; however, quantifying such "goodness" can be a demanding task for an IRO or for an investor relations scholar. Mills (1997) points out that not only do the investor relations professionals represent their companies in the investment community, but they also have important internal roles to provide strategic input and to participate in mergers and acquisition activities. They drive communications with investors proactively, concentrating on financial and strategic issues and setting the tone for the company's messages to its other audiences. 
Laskin (2009) found that the most common activities undertaken by investor relations executives were roadshows, presentations, conferences and responding to requests from shareholders, analysts, or stockbrokers. Among other activities investor relations executives named most often were providing information to top management or other departments of the organization, one-on-one meetings, negotiations, ownership research and analysis, and report preparations. Activities that also scored highly were management tasks and compliance with regulations and policies (p. 218). This means investor relations personnel often get to interact and work with CEOs of top companies, fund managers and other institutional investors.

According to Richard Jones, assistant vice-president of Thai Beverage, "To get investors to sit up and take notice of your company or client, investor relations professionals need to 'help in the interpretation of data and create a picture in the minds of stakeholders of where we are today, where we will be tomorrow, how we intend to get there" (Kok, 2008, n.p).

In the same report by Kok (2008), he quotes Elaine Lim, managing director of investor relations agency Citigate Dewe Rogerson i.MAGE, as saying that investor relations can be extremely challenging. It is vital to keep up with dynamic changes and developments globally and, more importantly, to understand their potential impact on local companies and develop strategic responses to take advantage of the positive developments and mitigate any potential negative impact. Kok (2008) is of the opinion that, "contrary to popular belief, investor relations practice is not merely touting the merits of a company. The job is not to always make the company look good whatever the cost. But it is to sell the company as is and as will be. Investor relations needs to talk about the company's virtues of course, but also needs to talk about things that went wrong" (n.p). 
One of the investor relations executive's tasks is to compile the company's annual report, and this requires sound financial and technical knowledge. According to Watson (2005), information is the investor's best tool when it comes to investing wisely. The annual report is a critical source of this information because it is the principal document used by most public companies to disclose corporate information to their shareholders. The U.S. SEC mandated this state-ofthe-company report for public companies in 1934 (Flanagan, 1993). Today, according to the SEC, annual reports are required for companies with more than $\$ 10$ million in assets whose securities are held by more than 500 owners. The reports are created to disclose information about a company's financial condition and business practices to help investors make informed investment decisions (The SEC, 2004).

These reports must contain basic information about a company expressed in both financial and narrative texts. The narrative texts, intended to supplement the report's required financial information, include the required Management's Discussion and Analysis (MD\&A) and the executive's letter (David, 2001). In the MD\&A, managers discuss and interpret the financial statements. The executive's letter, which is not mandated but is typically included as the first item in the report, is written as a signed personal letter from the president or CEO, providing an overview of past performance and discussing plans for the future (Yuthas, Rogers, \& Dillard, 2002).

Additionally, Hockets and Moir (2004) note that IR professionals should ensure that firms' equity are fairly priced and thus the effectiveness of investor relations might be regarded largely from the perspective of that of securities analysts or by volatility in share price. However, as investor interest in corporate social responsibility (CSR) grows, the role of investor relations also expands. 
The U.S. Social Investment Forum (US SIF) is a membership association for professionals, firms, institutions and organizations engaged in socially responsible and sustainable investing. According to U.S. SIF, socially responsible investing (SRI) is a broad-based approach at investing that encompasses an estimated $\$ 3.07$ trillion out of $\$ 25.2$ trillion in the U.S. investment marketplace today (2011). As a result of these investing strategies, SRI also works to enhance the bottom lines of the companies in question and, in so doing, delivers more long-term wealth to shareholders (U.S. SIF, 2011).

In fact, growth of socially responsible investment in the last decade has led to forms of investor pressure on firms to address issues of CSR and has made management actions more visible (Kahlenborn, 2002; Nelson Sofres, 2001; O'Rourke, 2002b). CSR activities are a distinct part of any large PR firm and CSR awards are given annually by PRSA and the Center for Corporate Social Responsibility at the National Press Club in Washington, D.C. In response to this, large firms now increasingly produce social reports as a way of communicating their perspective of their corporate responsibility towards social and environmental causes. This CSR has increased the IR responsibilities as well.

Marcus and Wallace, 1997 (cited in Hockets and Moir, 2004) state that the IR role has evolved through three phases: Initially the role of simple communication of the company's actions; an increasing focus on the financial function and financial results; and, finally, in more advanced companies, a trend towards active marketing to encourage investors to buy or hold the company's stock as well as to ensure that firms are fairly valued.

In Kok's views, the key to a successful investor relation's strategy is to build mutually beneficial relationships based on trust with shareholders and investors. He adds relationships are built on the quality and timeliness of information, so we may advise the company to be more transparent 
with information rather than less to help outsiders gain a better picture of the more authentic IR business.

\section{Educational Backgrounds}

Williams (2000) says:

'In the all important morning conference meetings, CEOs now want to see three people round the table: the lawyer, the banker and the investor relations officer. Investor relations practice is unique in that it deals with the highest levels within firms. By its very nature, you go straight to be board. Not only are you dealing with share prices and large deals, but also reputation management, of both the companies and the senior players in companies, no other form of communication does that' (p. 8).

According to Koh (1999), investor relations executives are experts who typically have some financial knowledge and a media background and who deal with queries analysts or fund managers may have about a company, so that the chairman and chief financial officer can concentrate on the firm's day-to-day business.

However, a survey conducted by Laskin (2009) addressed the educational background of IROs. More than $85 \%$ of all respondents had a business-related education in finance, accounting, management, or marketing. Only six respondents $(10 \%)$ reported a communication-related education such as journalism or public relations. Thirty-eight respondents $(60 \%)$ had a graduate education, with an MBA being the most often mentioned degree. 
Kok (2008) suggests that with investor relations diverse job tasks, essential communications and interpersonal skills also must include broader critical analytical skill. He says that, taking communication skills as a given, a good investor relations professional must be able to think, analyze and execute strategically given the dynamic capital market. It is also essential that the professional is numerate and able to read and analyze financial statements. Yet, Harrison (2000) reports that it's rare to find a college that teaches investor relations classes. He quotes Kelly Love, director of investor relations for Dallas-based Inet Technologies Inc; "It's better for students interested in the field to emphasize finance over communications. The National Investor Relations Institute is campaigning to get U.S. colleges to add courses on the field" (2000, p. 16). Recently NIRI has partnered with the University of California-Irvine and University of Michigan's Ross School of Business to develop investor relations certificate programs for executives with a few years of work experience in the field. The course durations vary from one to three semesters. The Department of Economics at University of San Francisco is also offering a three-semester-long investor relations masters degree program for executives. Few if any, schools in the U.S. appear to offer either a graduate or undergraduate course in investor relations. 


\section{Systems theory}

Owing to the dynamic nature of IR's work in terms of its various required skills and its professional's largely business-oriented backgrounds, systems theory seemed appropriate as a theoretical lens for this study. According to Skyttner (2001), the general systems theory is the skeleton of science in the sense that it aims to provide a framework or structure of systems on which to hang the flesh and blood of particular disciplines and particular subject matters in an orderly and coherent corpus of knowledge. Further, Kefalas (2011) states that each system is connected to another one in a serial, random or feedback fashion. In this image of the world, systems do not exist in isolation but are parts of a whole, namely, of the universe. Thus, one studies systems-within systems- within systems. As the term implies, it represents conceptual frameworks that conceive of real-world phenomena as systems.

Noticeably, a common thought that runs through the writing of systems theorists is the idea that all phenomena, if viewed as systems, "feed" on information. All systems are similar in that their function and evolution can be studied as inflows, processes and outflows of information. Kefalas (2011), illustrates this point through the example of a biologist who studies a cell or an organism by observing what it does and what it becomes, as a result of supplying or withholding certain information from the organism's environment. Similarly, the economist and the stock market analyst study behavior of the economy by tracing the impacts of certain kinds of information.

This brings us to the question: What is a system? Schoderbek, Kefalas and Schoderbek (1975) define a system as a set of objects together with relationships between the objects and their attributes connected or related to each other and to their environment in such a way as to form an entity or a whole. 
This study focuses on two of the major functions of the general systems theory (GST). According to the theory's author - Bertalanffy, "It was developed to encourage the proliferation of adequate theoretical models in fields, that lack them, and to promote the unity of science through improving communication among specialists" (Bertalanffy,1968, p.15).

Schoderbek (1967) was of the opinion that like any other general theory, GST may employ either one of two approaches:

The first approach is to look over the empirical universe and pick out certain phenomena, which are found in many different disciplines, and seek to build up general theoretical models relevant to these phenomena. The second approach is to arrange the empirical fields in a hierarchy of complexity of organization of their basic 'individual' or unit of behavior, and to try to develop a level of abstraction appropriate to each (n.p).

Although the theory has not yet been used to study investor relations specifically, public relations scholars have long used it. Pavlik (1987) suggested that a systems perspective is an emerging paradigm in public relations. In a chapter entitled, "An Emerging Paradigm: General Systems Theory", Pavlik said:

During the past decade, a number of scholars have conducted research to build a theoretical understanding of public relations. Emerging from this systematic perspective is a public relations paradigm based on the general systems theory.

Similarly, Long and Hazelton (1987) concluded that the general systems theory portends promise as meta-theoretical approach for organizing the field of public relations (p.4). In public relations literature, Bell and Bell (1976), introduced language and ideas of systems theory, distinguishing between a functional approach to public relations that took in to account that an 
organization and it's environment were mutually dependent and a functionary approach that did not. On the same lines, Mckee and Lamb (2005) suggest that in terms of public relations, the exchange occurs through the building of mutually beneficial relationships based on balanced flow of information from and to the organization and its open system. They add that according to the systems theory, the practice of public relations requires systematic ongoing environmental monitoring. Plans should be based on solid and thorough research that explores the internal and external situation of the organization and its system, which of course is important in any PR practitioners work, but is perhaps particularly crucial in investor relations activities. 


\section{Research questions}

Given the changing nature of investor relations practice and its growing importance to companies, this study seeks to answer the following research questions to help fill a void in the available literature about IR education.

RQ1: In what specific types of work do entry-level investor relations' practitioners engage?

RQ2: What do hiring managers at investor relations firms see as the largest knowledge deficit among entry-level employees?

RQ3: How important is formal communications education perceived to be for new hires?

RQ4: How does the communications role fit into the investor relations work system?

RQ4a: Where does the communications function fit in the IR unit's hierarchy of tasks? 


\section{Methodology}

To answer the research questions, the author administered online surveys to managerial level investor relations professionals at agencies and in-house investor relations departments. This method was selected because of its ability to reach a large number of professionals in a short span of time. The objective was to collect relevant data to help the author find explanatory answers to the research questions. Besides this, it was an inexpensive method, as respondents may be reached through emails. This also made the follow up process faster and inexpensive. Other scholars have also used this method to study IR in the past. According to Laskin (2009): 'Decision makers in businesses, consumer and activist groups, politics, and the media use survey results as part of their daily routines. Such a wide applicability of surveys is attributed to the following advantages of survey research: realistic settings, a large amount of data, no geographic constraints, and reasonable costs' (as cited by Wimmer and Dominick, 2003,p. 216).

\section{Online survey}

Research methodologies must be adjusted to accommodate the challenges of the research environment without compromising academic rigor. Hence this research study used online survey tools to reach out to prospective IR participants through a database (discussed below). A survey form was developed using the 'Select' package offered by the research website SurveyMonkey. With the help of the basic Hoover's database (details mentioned below), the author put together a list of 270 investor relations professionals with their email addresses. For this study the author choose the 'Select package' for a period of two months. This package offered unlimited survey questions per form and unlimited responses per survey. Additionally, the 'select' package offered features such as survey completion progress bar, real-time results, 
multiple custom reports, filtered \& cross tabulated responses by custom criteria and finally customized 'thank you' notes to the participants of the surveys.

With the help of the online research tools provided by the research portal SurveyMonkey, the author constructed a survey form with a set of nine close-ended questions and one open-ended question that urged the participants to express additional comments at the end of the survey form. The author pre-tested this survey using snowball sampling of three investor relations practioners. Based on their responses, revisions were made to the form with additional options to the multiple-choice questions in consultation with the committee members.

The author took great care in informing the participants of the survey and notifications to come, following recommended protocol provided by Dillman (2007). Before sending the survey, the author sent an introductory email to the selected population informing them about the study and requesting their participation. Through this email, the author let prospective participants know they should expect an email with the link to the survey the following week. This introductory email was sent during the third week of February 2012, following receipt of the study's approval by West Virginia University's Institutional Review Board (IRB). (See Appendix A for the IRB's approval.) The introductory email also offered an incentive to be provided at the end of the research study (Dillman, 2007). Specifically, the author offered to provide an executive summary of results to any interested participant to help further establish credibility and encourage participation. This was also mentioned in all following email correspondences to prospective participants. In the week that followed the introductory email, the author emailed the survey link to a list of 270 investor relations professionals. (Participants are discussed more fully below.) With this email, the author attached a cover letter (Appendix A), which explained the study's intent and also acted as a consent letter for the study. The cover letter explained the voluntary nature of the study and mentioned the Principal Investigator's contact details, which 
would prove useful if the participant had any doubts/questions/comments regarding the study. The email also urged the participants to forward the survey link to other IR practitioners. This helped the researcher apply the snowball survey method (also discussed below). Post this step, there were three rounds of follow-up emails sent to the prospective participants. These follow-up messages were spread over a period of three weeks with one email sent every week. After careful consideration, the author chose Wednesday as the day to send correspondences each week, because it intuitively seems to be a relatively less busy day than a Monday or a Tuesday and less relaxed than a Thursday or a Friday.

Additionally, the author also posted the survey link on various forums and communities on LinkedIn. IR professionals have created serious online communities on Linkedln to discuss important issues, trends and developments in the industry. Often, IR professionals raise queries, post informative quizzes and comments on these forums to disseminate information. The author of this research study is an active member of these IR communities. Hence, she was not required to seek permission to post the survey link on these forums. The following are the forums where the author posted the survey link: Investor Relations Network, Investor Relations Executives, Investor Relations Executives group, Investor Relations Organizations: IR, PR, Marketing, Advertising and Media Professionals Worldwide. IR professionals from different levels and ranks frequent these communities. This was an excellent opportunity for the author to gather different points of views. Owing to the separate SurveyMonkey link, there was no way to ascertain how many responses came from members of these forums, but the author did receive five emails requesting the complimentary copy of the study's executive summary and appreciating the efforts taken to study investor relations in detail. 


\section{Participants}

The sampling frame for this research study is based on the database provided by Hoovers Inc. Hoovers Inc offers proprietary business information through the Internet (Hoover's Online), Customer Relationship Marketing (CRM) applications (Access Hoover's), and integration with clients' existing enterprise infrastructure (Hoover's API). Its database of information includes about 65 million corporations and other entities and 85 million people, while its First Research product covers some 900 industries. However, limited access to the database along with budgetary constraints did not allow the author to administer the survey to the entire Hoovers database sample. Instead, the author compiled a list of 270 prospective participants. The existing Hoovers database mentioned limited details about the participants, which only included the name, designation, office phone number and office address. This information was inadequate since the author was using internet-based survey forms and required email addresses of IR professionals to reach them directly. Hence, based on the primary information that the Hoovers database provided the author put together a list of 270 IR professionals, which carries details such as name, company name, designation and most importantly email addresses. The author managed to find email addresses of individual participants by scouting through media and press releases available online, visiting investor relations sections of corporate websites, screening Linkedln profiles and on a case-by-case basis getting in touch with people directly.

While building this database, the author encountered a lot of issues. One of the main problems the author encountered was outdated information. Churn in the IR industry was not well documented in the database and often the author had to trace individual IR professionals to their new roles and hence update their details. The database also did not list IR professionals from consultancies. Hence there is poor representation of IR agencies in this sample set. The 
author carefully selected email addresses that belonged to individuals and eliminated the usage of group email addresses that started with either investorrelations@ or ir@. Most often, the latter do not reach individual participants and are dead leads.

In the past, a well-known investor relations scholar, Dr. Alexander Laskin has also used convenience sampling. Hence, the author, in consultation with her thesis committee, decided to use the nonprobability sampling technique for this study, while acknowledging that the findings/results are not generalizable. According to Zhou \& Sloan (2009), a convenience sample consists of individuals who are used as survey participants because they are easily accessible to the researcher. Additionally, snowball sampling is a type of convenience sample in which individuals participate in a survey through introductions to it by others who have participated (p.118). This method, which was also employed in this study, is commonly used to locate hard to find/identify participants. In accordance, Zhou \& Sloan (2009) suggest that researchers use snowball sampling when there is no list of participants readily available. In such cases, it is easier to ask the existing participants to name or recommend others in order to get an adequate number of interviews or responses. 


\section{Findings}

Answers to the study's research questions will be discussed below in terms of the survey findings $(\mathrm{N}=69)$, which had a response rate of no more than $25.6 \%$. (The author does not know how many prospective respondents saw the link on Linkedln forums or were sent the link through the snowball technique. Therefore, the response rate could be lower, but was calculated from the initial email correspondence to 270 prospective participants.) Despite this relatively low response rate, this rate is still higher than the average for Internet-based surveys in general, which can sometimes be as low as 1\% (Austin \& Pinkleton, 2006).

In the figures below, the ' $x$ ' axis represents the number of participants that selected a particular option ('y' axis), out of the total number of participants $(\mathrm{N})$ that responded to the question. While, the figures next to each bar show the percentage of respondents that choose a particular option out of the total number of respondents $(\mathrm{N})$.

RQ1: In what specific types of work do entry-level investor relations practitioners engage?

According to results of the survey question that asked people to choose from a list of tasks that entry-level IR executives perform the most, $72.5 \%$ of respondents out of the total number of respondents $(\mathrm{N}=69)$ suggested that collecting data and undertaking ownership research is most commonly performed by entry-level IR practitioners (Figure 1.0 ). Another $55.1 \%$ respondents reported that preparing and compiling the annual report, and $52.2 \%$ reported providing information to the top management and other departments. 


\section{What tasks are entry-level IR practitioners in your department/agency expected to perform?}

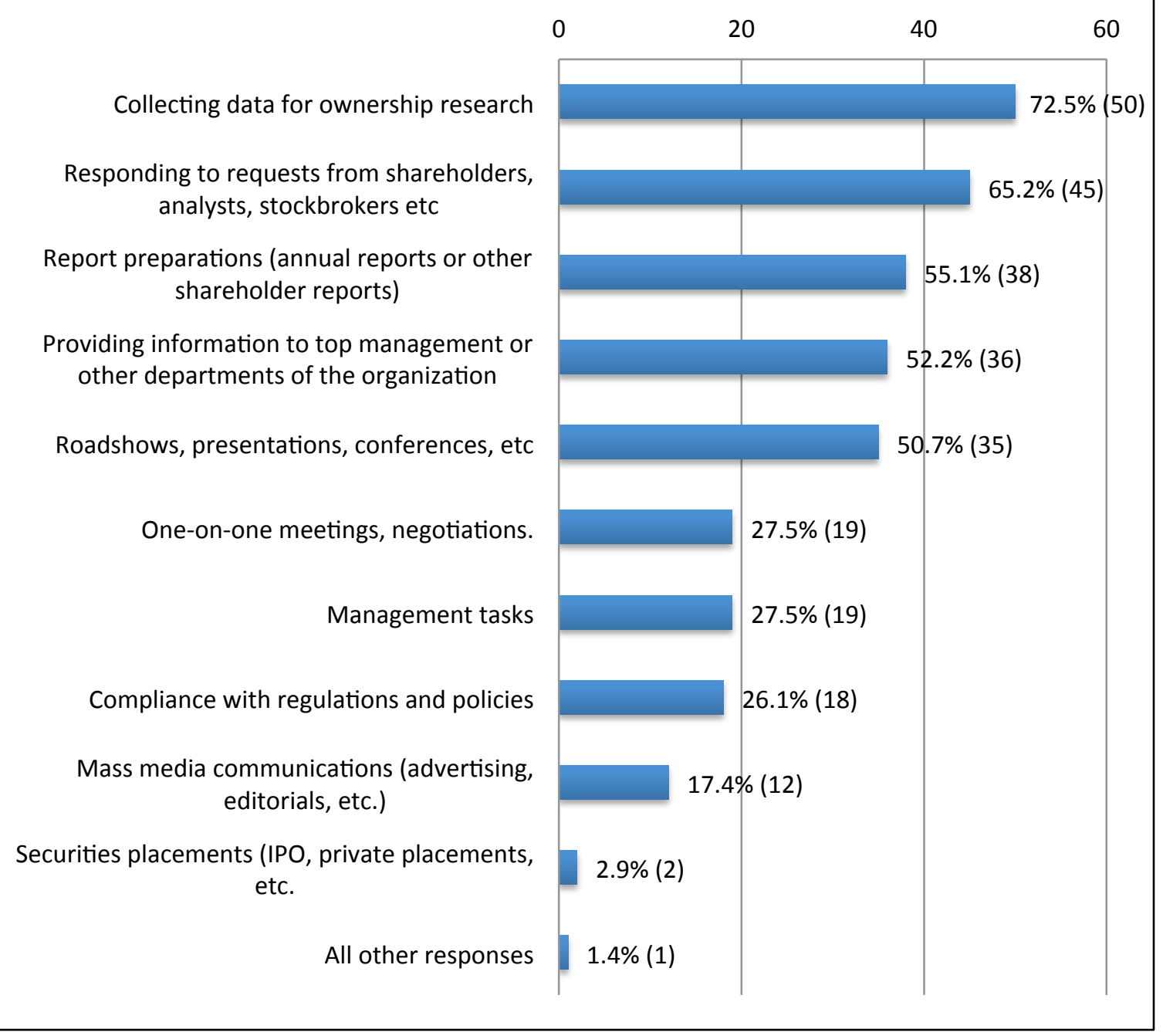

Figure 1.0

Supporting this latter finding were the additional comments section of this survey question, which included multiple entries by respondents suggesting that a new entrant in an IR department or agency is expected to research a variety of topics for the core team. One particular comment in this section also suggested that this research is part of the new entrant's initial training, as this process helps him/her to understand the industry and subject matter better. 
Other research-related responses in the open question included fact checking, filling in gaps with factual and statistical data, ownership research, competition analysis, market analysis and stakeholder database management. Among the other most selected tasks of entry-level IR professionals were organizing roadshows, managing presentations and conferences $(50.7 \%)$; managing one-on-one meetings and negotiations (27.5\%); undertaking management related tasks (27.5\%); and compliance with regulations and policies (26.1\%). Finally, only $17.4 \%$ of respondents selected interacting with the media and managing media-related activities as an option.

However, $65.2 \%$ of the total number of participants $(N=69)$ reported that entry-level IR practitioners respond to requests from shareholders, analysts and stockbrokers. Therefore, managing relationships with external stakeholders seems to be an important part of a new entrant's day-to-day responsibilities. In correspondence with this, another question in the survey asked participating IR professionals, which external stakeholders new entrants in the IR field interact with most often. The results ( $\mathrm{N}=68 ; 1$ missing) showed that entry-level IR practitioners most frequently interact with private investors (52.9\%;), stock analysts (51.5\%), and brokers (51.5\%). Additionally, $42.6 \%$ of the participants suggested that entry-level IR practitioners also communicate with institutional investors and fund managers. Interestingly, two comments in the additional response category of this survey question state that entry-level IR practitioners are not allowed to interact with investors and stakeholders until they've reached a certain level of experience/professional maturity in their positions. However, no specifics were mentioned regarding this level of experience/professional maturity. Figure 1.1 illustrates the wide range of external stakeholders entry-level IR practitioners interact with most frequently. 


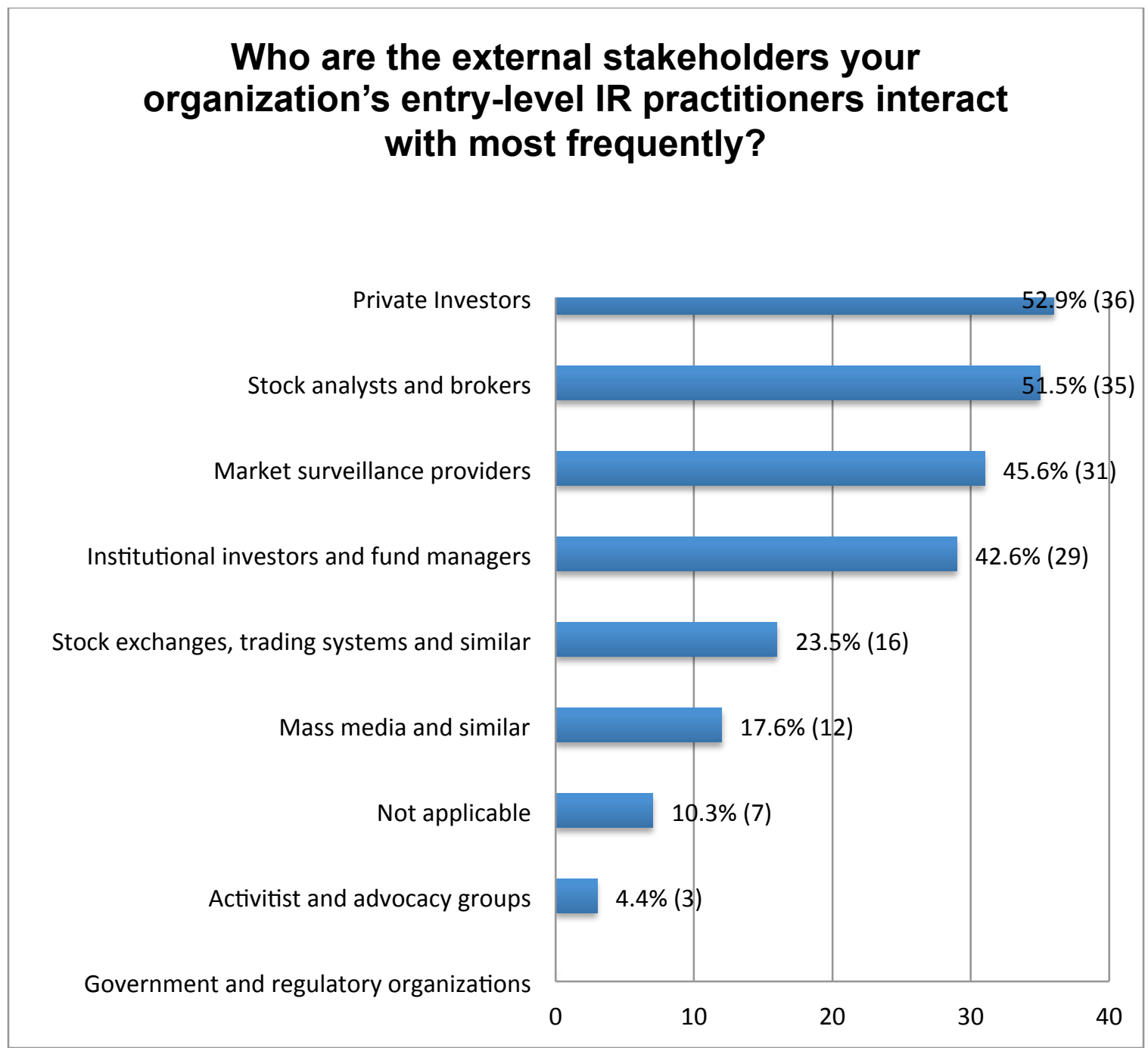

Figure 1.1 
RQ2: What do hiring managers at investor relations firms see as the largest knowledge deficit among entry-level employees?

Based on the responses to the survey question that asked participating IR practitioners to select from a wide range of skills that entry-level IR executives most lacked, $58.8 \%$ of respondents ( $N=68 ; 1$ missing) believed that these employees lacked proper writing skills. This stood out as the biggest inability among entry-level IR employees. Inadequate financial understanding $(52.9 \%)$ was also seen as an informational shortfall often noticed among new IR industry hires. Ranking third was lack of verbal communication skills at $30.9 \%$. An equal minority of respondents $(12$, or $17.6 \%)$ believed that entry-level IR practioners do not possess accounting abilities and legal knowledge. Figure 1.2 illustrates the wide range of skills IR professionals reported that new entrants most often lack. 


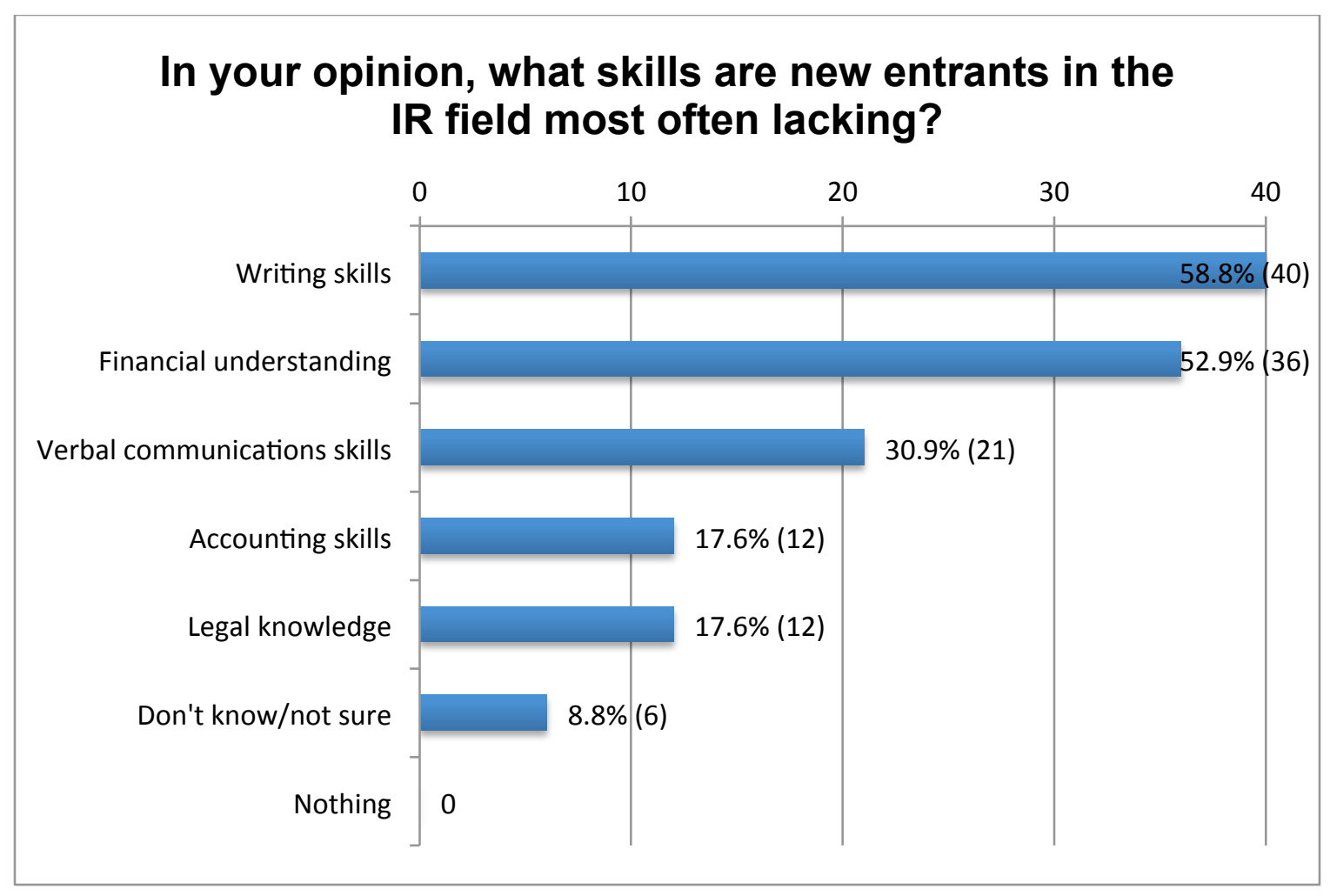

Figure 1.2

Comments in the open response category of the survey question suggested that new entrants in the IR industry should have, but often lack, basic knowledge of the working of financial markets, which is to be distinguished from the knowledge of finance and business. Secondly, they should also know the basic of securities law and compliance guidelines. Finally, they should possess computer skills, business etiquettes and presentation skills.

RQ3: How important is formal communications education perceived to be for new hires?

To establish a response for this research question, it is important to understand a variety of findings from the survey that will together attempt to answer it. As mentioned in the earlier response, two out of the three main knowledge deficits stated by IR practitioners were lack of writing and verbal communications skills. This suggests that communications is an important component of the IR environment, but to better understand its position in reference to the other 
essential skills, financial understanding and business acumen, the author needed to analyze other survey questions as well.

In the survey participants were asked to choose from a variety of academic coursework that entry-level IR practitioners should have taken to be considered for a position at the respondents' particular departments or agencies. In response, more than $87 \%$ of the total number of respondents $(\mathrm{N}=69)$ stated that finance would clearly give the new entrant an upper hand in the selection process. In comparison, communications coursework (note that public relations was listed separately) stood in the third position (55.1\%), after business, which followed finance at $60.9 \%$. Figure 1.3 illustrates the wide gap between these three primary courses as stated by participating IR practitioners.

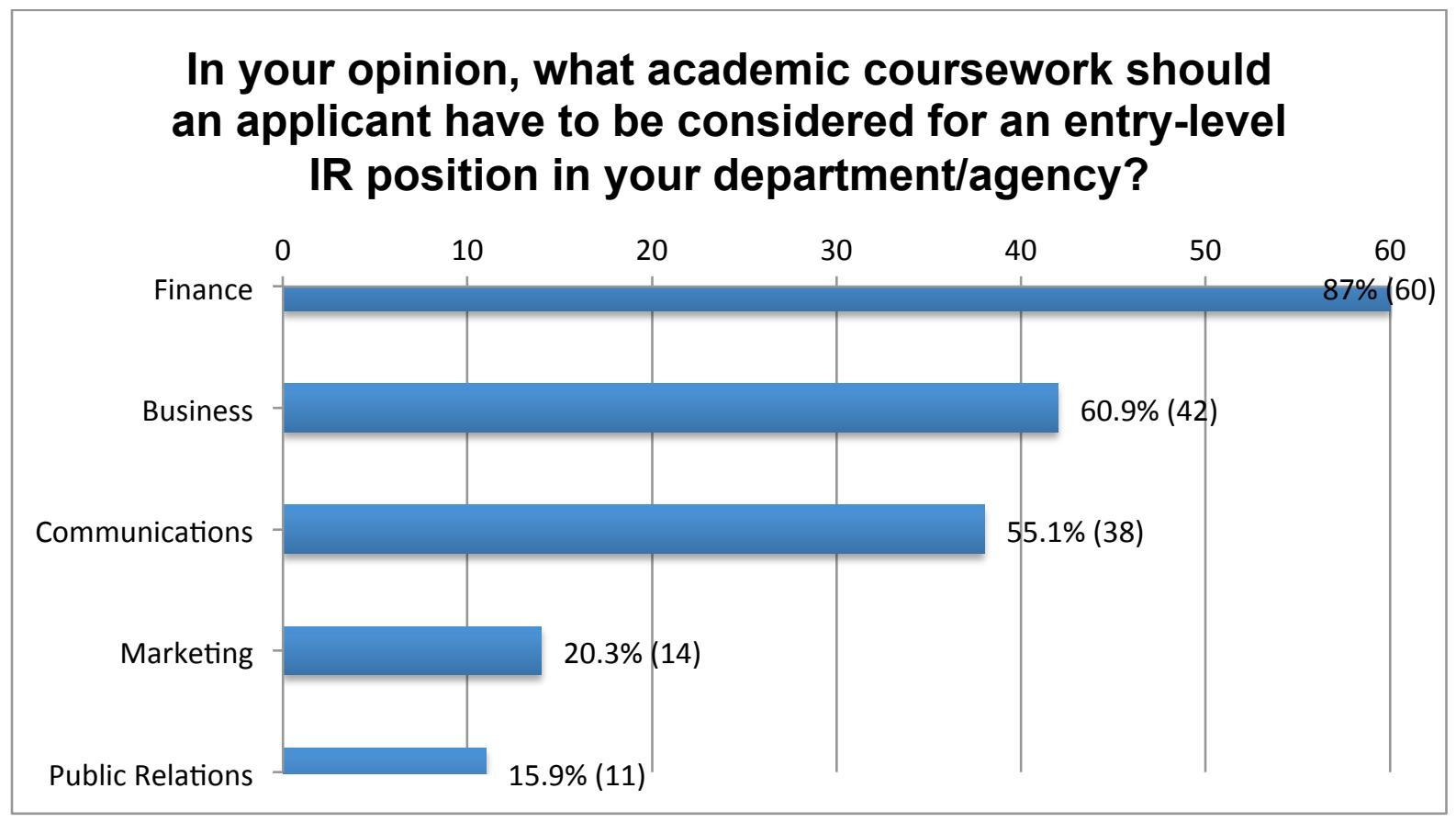

Figure 1.3

Additionally, marketing (20.3\%) courses were more popular among hiring managers in the IR industry than public relations courses at $15.9 \%$. 
Further, the author also asked the participants to choose from a variety of given options regarding their own respective educational backgrounds. Out of the total number of respondents ( $\mathrm{N}=67 ; 2$ missing), over $61 \%$ reported having finance-related academic backgrounds. Similarly, but listed separately, $41.8 \%$ reported having a business background; only $20 \%$ of respondents studied communications. Interestingly, more than $13 \%$ of respondents had academics in political science. Figure 1.4 illustrates the academic backgrounds of this study's participants.

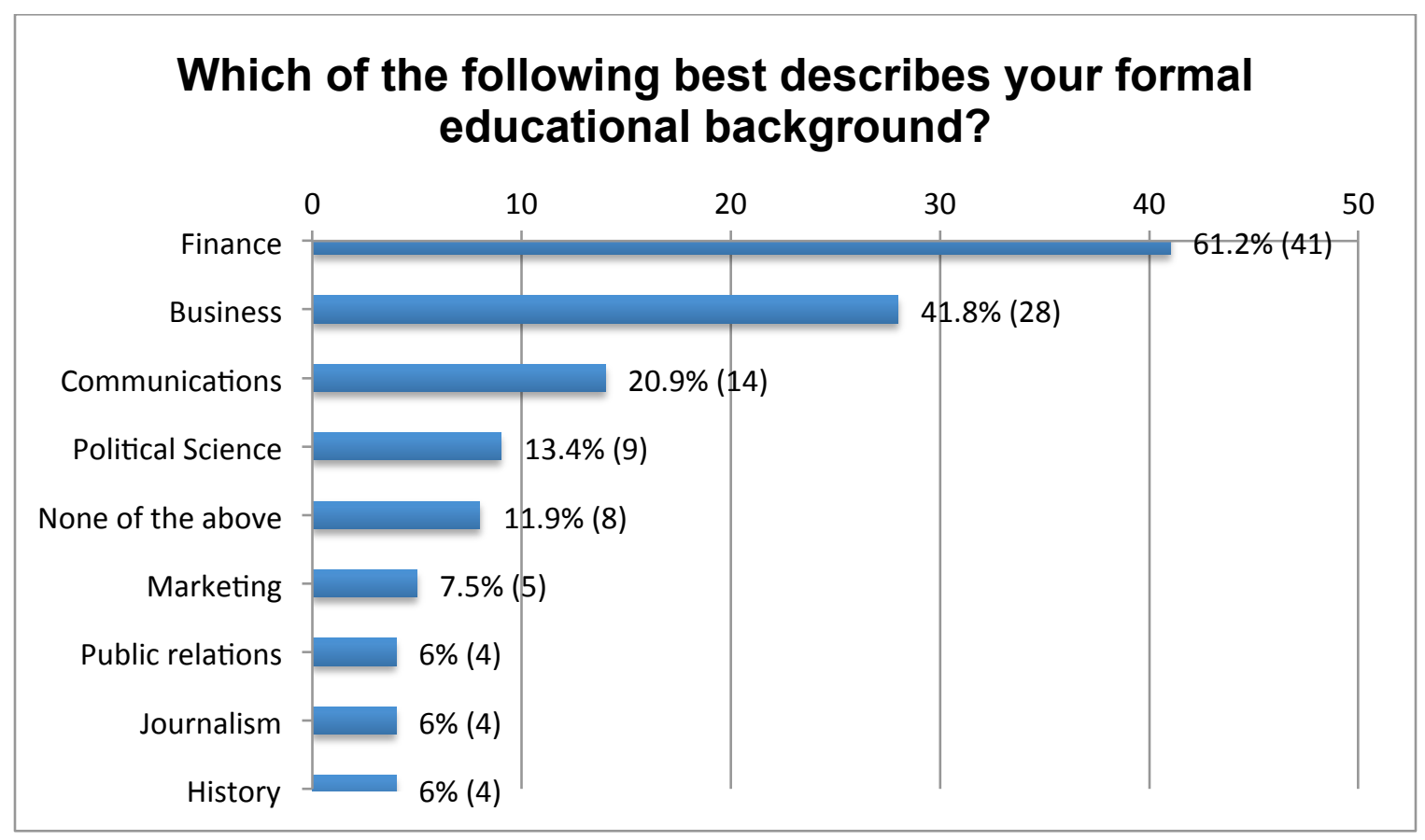

Figure 1.4

In the open response category economics, accounting and Chartered Financial Analyst (CFA) programs were commonly found responses. Other responses ranged from linguistics, languages, architecture and engineering.

Finally, the last question in the survey, which was designed to be an open-ended question and which gave participants an option to list all of the academic courses they believe to be essential 
for new IR industry employees, proved insightful. There were a total of 42 responses $(N=42)$ for this question. Based on the undergraduate and graduate course grouping listed in the West Virginia University course catalog, the researcher grouped the responses into seven broad categories of courses: Finance, Business, Communications, Social Sciences, Languages, Legal, and Industry-specific courses such as Pharmaceutical, Statistics, and Technology. The most commonly reported responses by group were Finance and Business courses. In the Finance category, the most common responses were accounting, financial statement analysis, corporate finance, regulatory finance, and valuation. In the Business category, respondents specified economics, macroeconomics, marketing, markets, and business development.

A large number of respondents (26) stated that entry-level IR practitioners should have a strong background in communications. Suggested communications coursework included courses involving writing skills, presentation skills, media management training, journalism, public relations, corporate communications, and basics of advertising and graphic design. Finally, 39 responses suggested that a strong preparation in research skills was an essential attribute for entry-level IR practitioners.

RQ4: How does the communications role fit into the investor relations work system?

As we've already covered in response to the first research questions, the four most commonly reported tasks performed by entry-level IR practitioners are: collecting data for ownership research; responding to requests from shareholders, stakeholders, analysts and various other publics; annual report preparation; and organizing roadshows, conferences and presentations. In each of these tasks, communications and related skills play an extremely important role.

As noted earlier, entry-level IR practitioners interact with a wide range of external and internal stakeholders. According to the results of this study, among the top five external stakeholders with whom new IR entrants interact most often are private investors, stock analysts and brokers, 
market surveillance providers, institutional investors and fund managers, authorities from stock exchanges and trading systems. Similarly, a survey question that asked participants to select from a wide range of internal publics, ones that entry-level IR practitioners interact with the most, resulted in $76.8 \%$ of the total number of respondents $(N=69)$ reporting that entry-level practioners interact with their finance departments the most. The management and communications departments were each specified by $66.7 \%$ of respondents. Together, they shared the second position. The legal department and employees were reported by $49.3 \%$ and $34.8 \%$ of respondents, respectively. Figure 1.5 illustrates these responses.

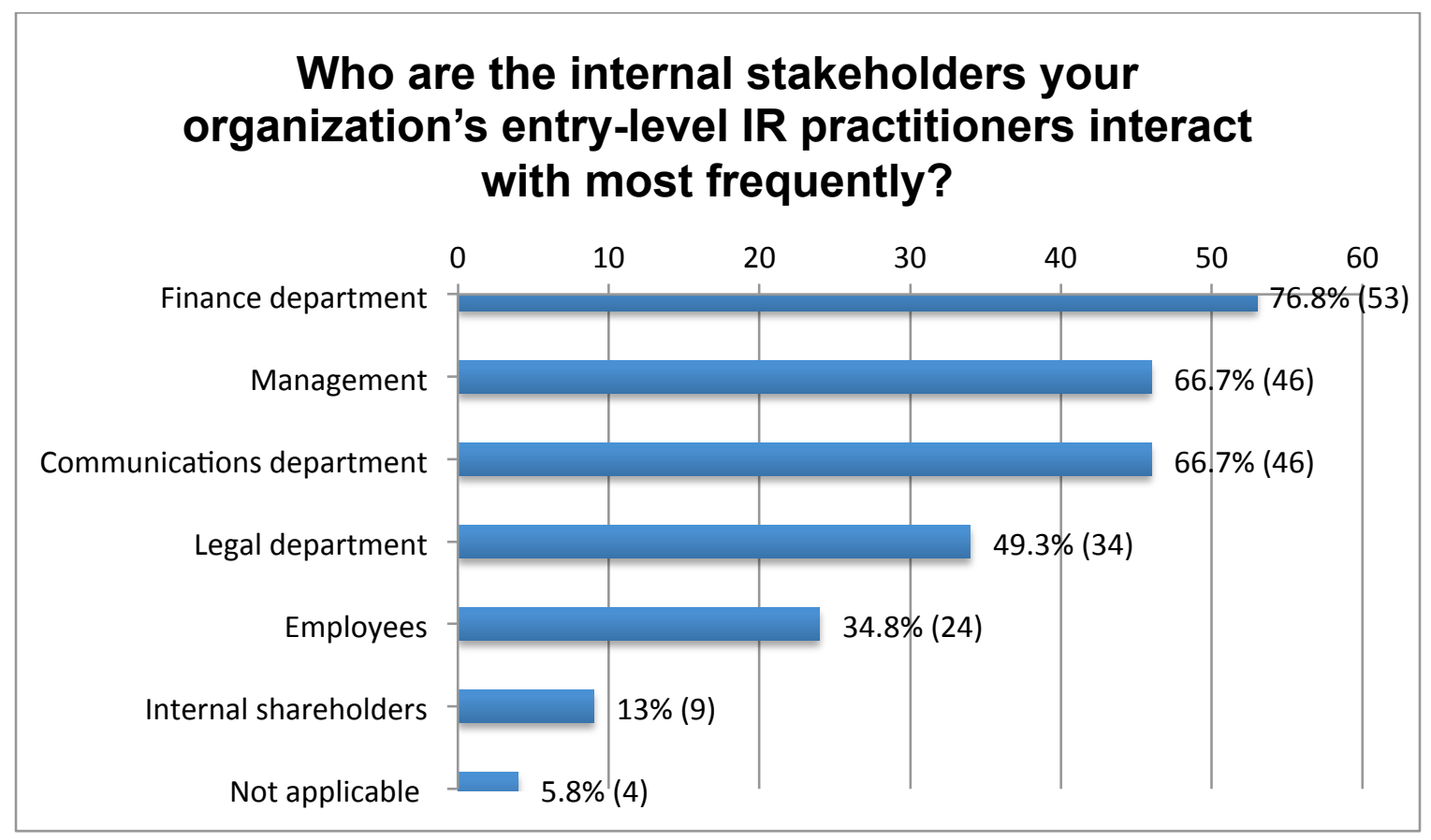

Figure 1.5

Responding to queries and requests from external as well as internal publics constitutes an important responsibility of entry-level IR professionals. These tasks require a range of communications skills, such as effective interpersonal skills, and good writing and negotiation skills. 
As mentioned earlier, preparing the annual report is one of the most important instruments through which IR departments reach their stakeholders and ensure they are informed about the developments in the company. In addition to sound financial and technical knowledge, preparing an annual report also requires skills found in journalism, marketing communications and/or public relations courses, such as data gathering, interpersonal and coordination skills with various publics, technical writing, editing and designing, and mailing list management skills. Similarly, tasks such as organizing roadshows, meetings, conferences and presentations require event organizing and management skills, vendor management skills, understanding of business etiquette and efficient presentation skills. Overall, although the IR field appreciates sound financial knowledge and business acumen, it seems clear that entry-level IR practitioners are expected to be good communication managers as well.

RQ4a: Where does the communications function fit in the IR's unit hierarchy of tasks?

As discussed when answering previous research questions, the communications function appears to be inherently woven in the hierarchy of tasks performed by entry-level IR practitioners. Supporting this finding, results of a survey question that asked what entry-level IR candidates are tested for during job interviews showed that about $92 \%$ of respondents $(\mathrm{N}=68 ; 1$ missing) tested for financial understanding. This is followed by verbal communication skills and writing skills at $89.7 \%$ and $83.3 \%$, respectively. Figure 1.6 illustrates the responses to this question. 


\section{When screening applicants for entry-level positions in your IR department/agency, what skills does your company specifically look for?}

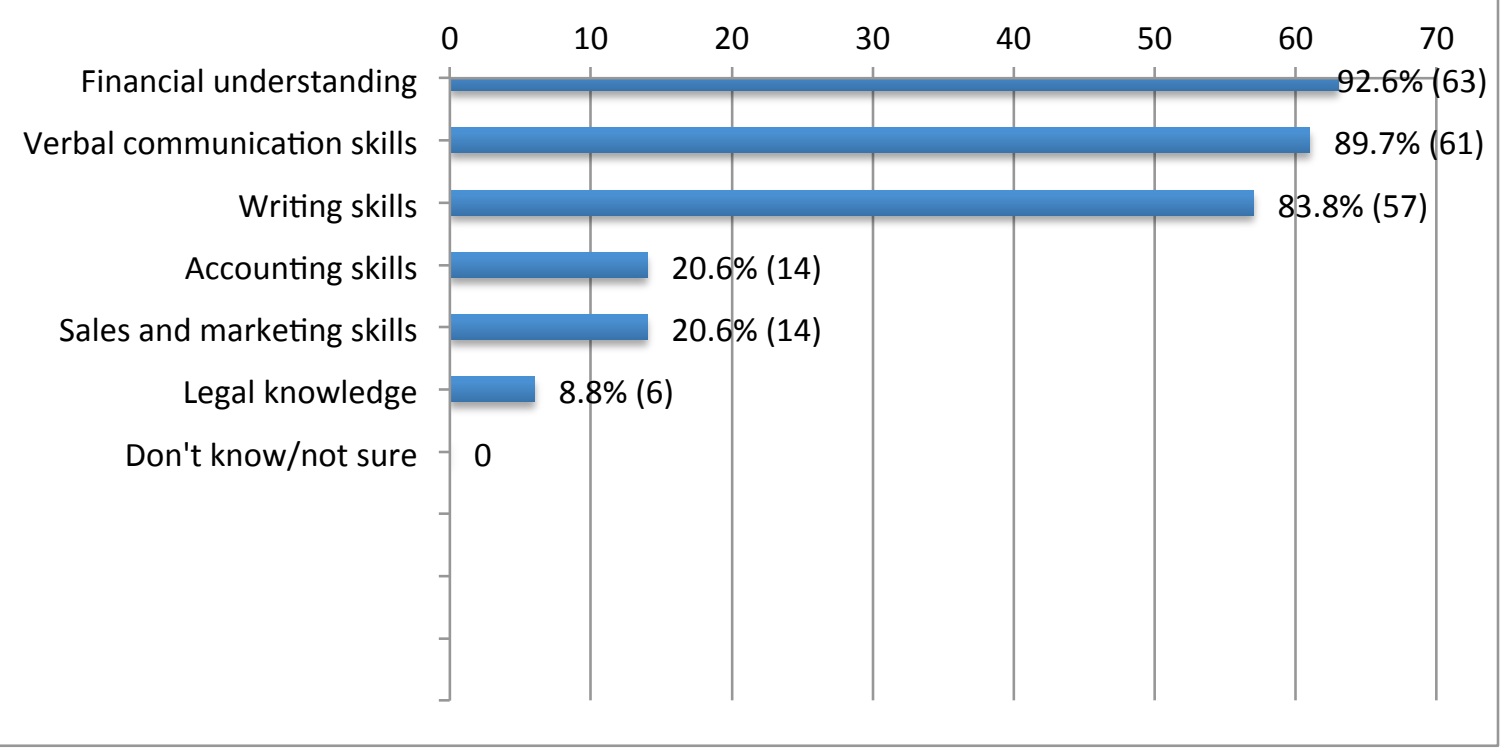

Figure 1.6

In addition to these results, the overall survey findings indicate that the communications function, while essential, is considered secondary to financial understanding and business acumen when selecting entry-level IR practitioners.

One other noteworthy aspect of the survey findings was the level of experience that the IR practitioners who participated in the study possessed. More than 31 participants of the 68 (1 missing) who responded to this question had more than ten years of IR work experience; 24 participants had between one to five years of experience. Figure 1.7 illustrates the survey respondents' years of IR work experience. 


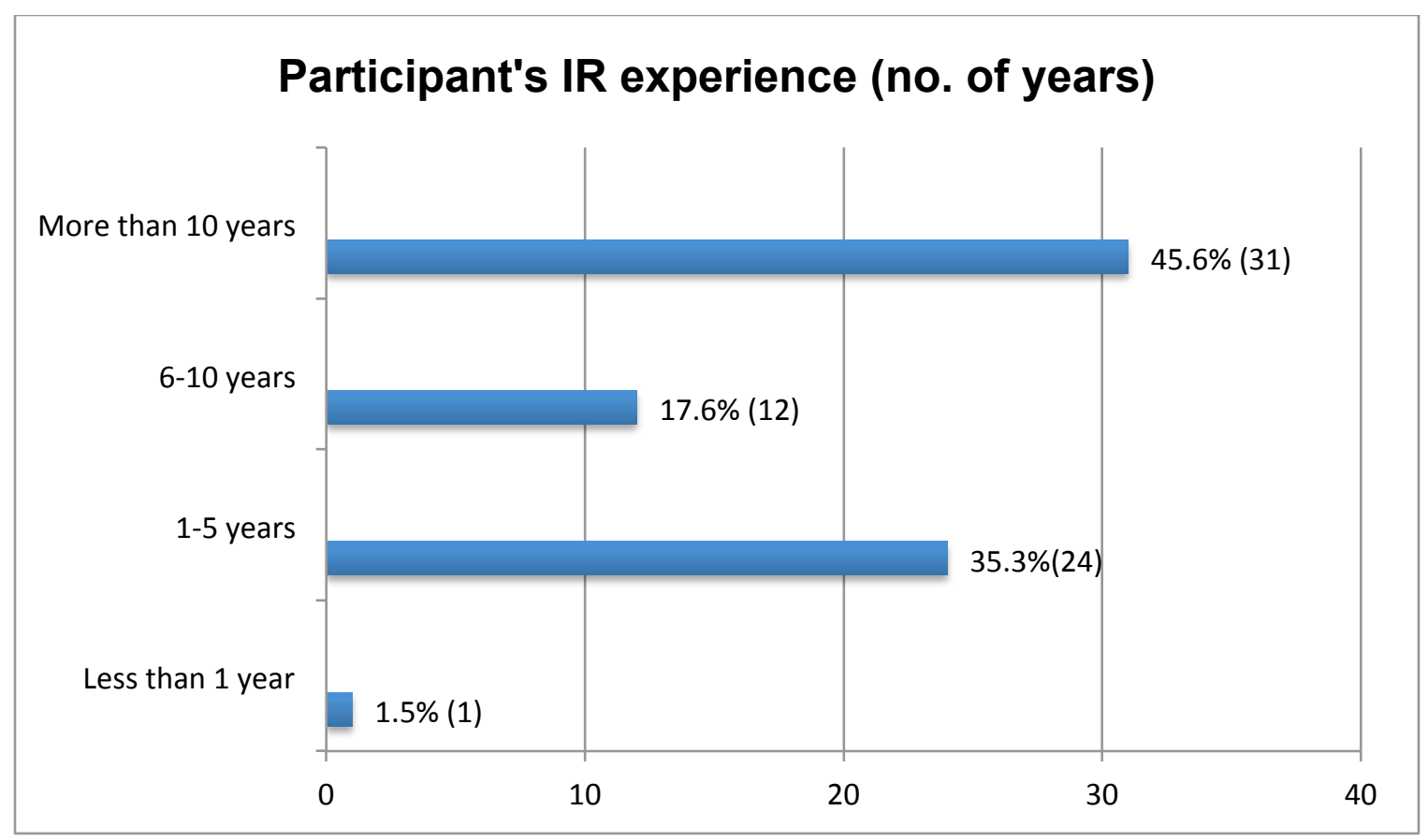

Figure 1.7 


\section{Discussion}

Based on the research findings of an online survey designed to understand the academic backgrounds and proficiencies required of entry-level IR practitioners, a number of observations were made.

\section{Tasks}

In accordance with the results of the first research question regarding the tasks performed by an entry-level IR executive, in the literature review, Laskin (2009) too suggested that the most common activities undertaken by investor relations executives were roadshows, presentations, conferences and responding to requests from shareholders, analysts or stockbrokers. In the same study, Laskin noted that among other activities that investor relations executives named most often were providing information to top management or other departments of the organization, one-on-one meetings, negotiations, ownership research and analysis, and report preparations. Activities that also scored highly were management tasks and compliance with regulations and policies. The findings of Laskin's study coincide with the results of this research study, which confirms its relevance to the IR industry. The only difference is that Laskin's study was trying to understand the tasks performed by IR practitioners in general, while this study looks at activities undertaken at the entry-level only.

\section{Audiences}

It has also been noted in the literature review, Gilfeather (2003), that IR executives tend to pay less attention to individual investors as compared to institutional investors. One main reason cited for this is that institutional investors make huge investments in a corporation, which in turn brings a sense of stability. Additionally, they are also prime targets due to compliance and 
marketing reasons. While interaction with institutional stockholders is more common among those in senior- level IR practice, the results of this survey suggest that entry-level IR executives interact most frequently with private investors. This may support Haas's (1991) observation that individual investors now own the majority of most corporations' shares; therefore, one assumes these investors are receiving greater attention from IR practitioners, and it seems it may be the entry-level ones.

Similarly, Haas (1991) suggested that IR executives are increasingly interacting with the media. The number of pitches to the media by IR executives has seen a surge in the recent years. The results of this research study point out that $17.6 \%$ of the 68 respondents believed that entrylevel IR executives interact with the media on a daily basis. This may indicate that there are exchanges of ideas among the IR executives and the media.

While Corporate Social Responsibility (CSR) is seen as a developing function for IR executives (U.S. SIF, 2011), the activities mentioned in the survey are distinct from the ones IR executives engage in. Activities in relation to CSR undertaken by IR executives at any level involve skills and expertise of a communications generalist, which is to be distinguished from being directly involved in the process of supporting a cause and raising money for this cause as a part of the company's CSR activities.

\section{Skills and Education}

According to the results of the survey, writing skills, financial understanding and verbal communications skills were the three important skills that entry-level IR executives lack most often. Two out of these three skills are communications based. Also responses in the open response category of the same survey question stated that new entrants often lack presentation skills and business etiquettes. This suggests that there is an urgent need to integrate communications_-and public relations—courses in the investor relations academic stream. 
Among the tasks entry-level IR executives undertake, research proved to be a popular response amongst participating IR practitioners. In this context, Deloitte LLP and APEC Studies \& Research Department recently conducted a study on the skills and competencies required to succeed in research. This study suggested that in addition to scientific competencies and personal aptitude, research demands interpersonal, project and team management skills. These include: ability to work in a team, communication skills, language skills, business culture and management skills, awareness of the pertinence of the research and its impact on the environment and an open-minded approach (Lamblin and Etienneby, 2010 p. 7). This indicates that communications components are an integral part of research and hence when new entrants in the IR field undertake research activities they require specific communications skills.

Although, the results of another survey question in this research study, asked hiring IR manager to choose from a variety of skills that they most often test entry-level candidates for, indicated that financial understanding and business acumen are considered to be more important skills at an entry-level in an IR department or agency.

Similarly, when asked about the preferred academic background of an entry-level IR candidate, IR practitioners picked finance and business as their most preferred options. This was followed by communications. It is important to note that an academic program in public relations was voted as the least preferred area of studies for an entry-level IR participant. As noted in this study's introduction, investor relations practitioners have for years consciously distinguished themselves from financial public relations practice.

The National Investor Relations Institute (NIRI) famously used the term 'separating the wheat from the chaff' to differentiate themselves from public relations executives (Morrill, 1995). Officers at the NIRI believe that the two professions deal with completely different arenas and audiences. However, it is worth noting that the field of investor relations assigns importance to communications skills, but courses in public relations, which help students hone their 
communications skills, are to a large extent ignored. There could be multiple reasons for this differentiation, one of them being the age-old hostility mentioned above. Another could be ignorance as to what public relations curricula include.

Interestingly, the majority of survey respondents also had academic backgrounds in finance and business. Laskin (2009) found similar results in a survey conducted that explored the educational background of IR practitioners. According to Laskin, more than $85 \%$ of all respondents had a business-related education in finance, accounting, management, or marketing. Only six respondents $(10 \%)$ reported a communication-related education such as journalism or public relations. Thirty-eight respondents $(60 \%)$ had a graduate education, with an MBA being the most often mentioned degree. It is important to note here that Laskin includes finance under the broad category called business-related education. While in this research study, the author has clearly differentiated between the two academic streams: business and finance. These have resulted in refined responses.

As mentioned earlier in the literature review, NIRI has partnered with the University of California-Irvine and University of Michigan's Ross School of Business to develop investor relations certificate programs for executives with a few years of work experience in the field. Even then, these short certificate programs are structured to attend to the needs of busy investor relations professionals. Very little attention is paid to structuring programs at an entrylevel for investor relations professionals. There is a requirement for academic institutions to begin working on developing curriculum for investor relations programs with an intelligent mix of coursework in finance, business, communications and other required subjects. The author would also suggest NIRI to devise an integrated curriculum of essential and additional coursework that could be adopted by academic institutions all over the U.S. 
In addition to this, in an academic setting, it is extremely important that different academic energies come together to form this program in investor relations. To elaborate, various departments in the university such as finance, business, communications, legal, economic, English, accountancy etc need to work together to build a concise program for investor relations.

Keeping in mind the tasks performed by the entry-level IR practitioner on a day-to-day basis, a solid communications background cannot be ignored. Hence, these results suggest that while formal education in communications is necessary, it is not considered to be the required academic coursework while hiring a new entrant in the IR industry. Nevertheless, it is evident through this study that writing, verbal communications and presentation skills are commonly required by IR professional and are not considered optional in the industry.

Another point worth noting is that $63.8 \%$ of the total number of respondents $(N=69)$ said that they do not have formal in-house training for new entrants in their firms. However, open responses to this survey suggested that on-the-job training is a popular medium of preparing new hires to better manage their IR jobs. These responses suggested that collecting data and conducting research is an excellent way for the entry-level IR executives to learn and understand the profession faster.

Overall, in other words, as mentioned earlier in the literature review, Laskin (2009) said that investor relations is a practice on the borderline of business and communications, and synergy between these two areas is essential. In correspondence with this, the results of this research study suggest that the scale weighs lighter on the communications side, but at the same time without it, there would be an imbalance of education and expertise in the field of IR.

In recommendation, the author would advice schools to consider IR as an important and lucrative field for recent graduates. As mentioned earlier in the literature review (Harrison 
(2000)), schools in the U. S. need to introduce Investor Relations programs. It has been observed from the results of the survey that there is an immediate requirement for training new entrants in a variety of skills, dominated mainly by financial knowhow and communications skills to prepare them for a successful career in IR. The author would suggest educational institutions and academic programs to include modules to help inculcate and enhance effective communications skills among new entrants in the IR field. It is also evident through this study that investor relations programs should have some public relations courses, which will help streamline any media functions and activities IR executives undertake.

Individuals who are looking at entry-level positions in IR departments and agency could take suggestions from the results of this study. Some of the important observations of this study on tasks performed, skills required and preferred academic backgrounds would help undergraduate students take a variety of courses in the academic fields of finance, business and communications to make themselves eligible for entry-level opportunities in the IR industry. Finally, through this study, entry-level IR executives will be exposed to a wide range of skills they can inculcate and enhance. Alternatively, compensating skills that they lack at with the ones they are exceptionally good at will help a great deal. 


\section{Limitations}

This research study has important limitations, which do not permit the results to be generalizable beyond its survey respondents' experience. First, the database used for this study represents a very small and nonrandom sample of the representative population. Therefore, the small sample size and use of nonprobability sampling methods (convenience and snowball sampling) are the study's largest shortcomings

To be more specific, the author of this research study sent out survey links to 270 investor relations professionals that were based in the U.S., but in snowball sampling participants are urged to take the survey through referrals and introductions. The author does not have any control over the multiplication of this existing sample. Hence, the researcher cannot regulate the demographic and geographic details of this population. In a similarly related issue, the author posted the survey link on various investor relations communities formed over LinkedIn.

Membership to these communities is open to IR professionals all over the world. The author received requests for executive summaries of the research study from IR professionals based out of different countries, including India, Japan, and Dubai. This does not necessarily suggest that these professionals participated in the survey, but the possibility cannot be denied either. What it does indicate is that the topic of U.S. IR practitioners' preparation is of interest internationally.

Another limitation of this study was an unequal representation of investor relations professionals who worked with IR agencies. While building the database, the author noticed that the original Hoovers database did not have any representation of IR professionals who worked with U.S. agencies. In an attempt to include agencies in this research study, the author included a few IR professionals that were found through media and press releases, but they were far fewer than 
the number of corporate practitioners' names. Hence, there is an unequal representation of IR agencies in the sample population.

It has been noticed in the course of this study, that educational categories of communications, public relations and marketing may not have been clearly defined and hence participating IR professionals might have faced confusion and difficulty distinguishing them. It proves to be a very important limitation in this study, because skills and expertise required in the field of communications, marketing and public relations often overlap and hence a clear distinction among these educational categories is essential.

Additionally, the research portal, SurveyMonkey, which hosted the survey form and analyzed the results proved to be inadequately equipped to analyze permutations combinations of these results. The analysis that this research portal enabled was at a very basic level and did not allow the researcher to dig deeper and unearth interesting findings other than the most obvious ones.

The last limitation of this research study was the technical difficulties that the researcher faced while obtaining the IRB approval to undertake research that includes testing (in this case administering online surveys) human beings. The approval for the proposed research that usually comes through in a few weeks after the application, took two months to come through. The reason for this was technical difficulties in the system that were faced by both the IRB team and the researcher. Had this process not been delayed, the researcher would have had a bigger timeframe to complete the research process, instead of the four weeks in this case. Also the researcher likely would have been able to reach more prospective participants, which could increase the reliability of the results. On a positive note, the high proportion of participants with more than ten years of work experience mean that collectively, respondents shared centuries of IR experience. 


\section{Future research}

Since this study was restricted by the above-mentioned limitations of nonprobability sampling, the external validity of the results is compromised. The study could be strengthened by being replicated—and perhaps expanded—with a large, more representative probability sample.

Researchers could also conduct additional qualitative research to better understand and expand upon the survey responses obtained in this study. For example, interviews (personal or in-depth methods) of investor relations professionals could help uncover more detailed insights regarding the issues entry-level investor relations professionals face on a day-to-day basis. Focus group interviews could also be beneficial. Healthy discussions among IR professionals would help bring out important aspects of the field.

As mentioned earlier in the limitations for this study, clearly defining academic coursework in communications, marketing and public relations in the future would help participants make decisions based on the distinctions between these fields. This will help in understanding the responses better and enhance the final results.

Related research topics could include testing the different combinations of academic coursework in finance, business, communication, law etc, currently offered by schools that hosts investor relations programs and gauging among these, which combinations work better. Also, researchers in the future could study the minute differences between investor relations and financial public relations, the different levels of expertise and education that are required for investor relations and financial public relations, and/or could also test the differences between the working professionals in an IR department (corporate).

This exploratory study helped contribute to the relatively scarce literature involving the education and skills required of investor relations practitioners and explored how 
communications fits into the profession's overall demands and workflows. Its results may help both interested students and educators make their curricula more meaningful and marketable. Because, relatively speaking, there is a dearth of literature in this area, additional studies that can further define formal curricula and meet students' and practitioners' needed knowledge and skill sets are welcomed. 


\section{References}

Allen, C. E. (2002). Building mountains in a flat landscape: Investor relations in the post-Enron era. Corporate Communications, 7(4), 206-211.

Argenti, P. A. (2002). The fast forward MBA pocket reference (2nd ed.). New York: John Wiley.

Austin \& Pinkleton (2006). Strategic Public Relations management. Planning and managing effective communication programs. Second Edition, p. 209

Bell, S. H., \& Bell, E. C. (1976). Public relations: Functional or functionary? Public Relations Review, 2(2), 47-57.

Bertanlanffy, V. L (1968). General Systems Theory.

Columbia University of New York (2011), Columbia University Human Research Protection Program. Retrieved from: http://www.columbia.edu/cu/irb/

David, C. (2001). Mythmaking in annual reports. Journal of Business and Technical Communication, 15(2), 195-222.

Dillman, D.A. (2007). Mail and internet surveys: The tailored design method (2 ${ }^{\text {nd }}$. Ed.). New York: John Wiley \& Sons.

Dorel, M., Marian, S., Elena, H., Cristian, H. \& Dorel, U. (2010). The evolution of the economical and financial communication means used by the companies in the new current world context. International Journal of Academic Research, Vol. 2 Issue 4, p332-337, 6p

Favaro, P. (2001). Beyond bean counting: The CFO's expanding role. Strategy \& Leadership, 29(5), 4-8.

Farragher, E. J., Kleiman, R., \& Bazaz, M. S. (1994). Do investor relations make a difference? Quarterly Review of Economics and Finance, 34(4), 405-412.

Flanagan, P. (1993). Make your annual report work harder. Management Review, 82(10), 52-58.

Goodman, G. (2004). Sarbanes-Oxley: Are we there yet? Retrieved from: November 18, 2004, from http://www.sarbanes-oxley.com/

Haas. T. A, (1991), New realities in investor relations. Public Relations Quarterly, 36(3), p17-19, $3 p$

Harrison. C., (2000, September 3), Investor relations pros find own ways to the job, The Dallas Morning News, (Employment), pp. 16L.

Heylighen, F \& Joslyn, C. (1991). What is systems theory? Principia Cybernetica Web, Retrieved from: http://pespmc1.vub.ac.be/systheor.html 
Hines, R. \& Basso, J., (2008). Do Communication Students Have the "Write Stuff"?:

Practitioners Evaluate Writing Skills of Entry-Level Workers. Journal of Promotion Management, Vol. 14 Issue 3/4, p293-307, 15p

Hockets. K. \& Moir. L, (2004). Communicating corporate responsibility to investors: The changing role of the investor relations function. Journal of Business Ethics - 52, pp. 85-98.

Hogan. A. D, (2009). Reaching shareholders online: trends and best practices in online communication and social media in corporate Investor Relations. Presented at the 2009 Annual Conference of the International Association of Online Communicators, Washington, D.C.,

Joyce, S. (2009). Institutional investors and analysts increasingly using blogs and social networks for research. Retrieved from http://www.q4blog.com/2009/09/23/institutionalinvestors-and-analystsincreasingly using blogs and social networks for research/

Kahlenborn, W. (2002). The social and environmental impact of SRI - Results of past research. Report of the Eurosif Conference April 2002', EUROSIF Conference, April 2002, Frankfurt.

Kelly. K.S, Laskin, A.V. \& Rosenstein, G. A. (2010) 'Investor Relations: Two-way symmetrical practice, Journal of public relations research, 22:2, $182-208$

Kefalas, A.G. (2011). On Systems Thinking and the Systems Approach, 67:4-5, 343-371

Kefalas, A.G. (1996). Review of the Democratic Corporation by Ackoff, Russell. March. Pp. 332 $-333$.

Kok. C., (2008, March 17), Getting investors to sit up and take notice; Charmian Kok looks at the role of investor relations professionals. The Business Times Singapore.

Koh. E., (1999, October 5). Firms value investor relations. The Straits Times, (Money), pp. 56.

Laskin. A.V., (2007), The value of investor relations: A delphi panel investigation, Institute for Public Relations study.

Laskin, A. V., (2009). A descriptive account of the investor relations profession. Journal of Business Communication, Vol. 46 Issue 2, p208-233, 26p.

Laskin, A. V., (2006). Investor relations practices at Fortune 500 companies: An exploratory study. Public Relations Review, Vol. 32 Issue 1, p69-70, 2p

Laskin, A.V. (2005, March). Investor relations practices at Fortune 500 companies: An exploratory study. Paper presented at the 8th Annual International Public Relations Research Conference. Miami, FL..

Lamblin. P., \& Etienne. C., (2010). Skills and competencies needed in the research field objectives 2020. Study conducted by APEC and DELOITTE Consulting Public Sector, p. 7

Long. L.W., \& Hazelton. V., Jr. (1987). Public relations: A theoretical and practical response. Public Relations Review, 13(2), 3-13. 
Luoma-aho. V., (2009). Love, hate and surviving stakeholder emotions. Conference Papers -International Communication Association.

MacGregor, J., \& Campbell, I. (2006). What every director should know about investor relations. International Journal of Disclosure \& Governance, Vol. 3 Issue 1, p59-69, 11p

Marcus, B. W. and Wallace, S. L. (1997). New dimensions in investor relations: Competing for capital in the $21^{\text {st }}$ Century. John Wiley \& Sons, New York.

Mckee. K. B. \& Lamb. L. (2009). Applied Public Relations: Cases in Stakeholder Management, Second Edition. Pp. 1-7

Mills. A., (1997, July 4), The coming of age of investor relations - investor relations is growing to meet the increasingly influential role of shareholders in corporate strategy, says Andrew Mills, PR Week.

Michaelson. D., \& Gilfeather. J.,(2003). What you need to know to measure investor relations, Institute for Public Relations study.

Morgenson, G. (2002, May 5). Information sooner, yes, but make it better, too. The New York Times, Market Watch, p. 1.

Morril, D. C (1995). Origins of NIRI. Retrieved February 17, 2007, from http://www.niri.org/ about/origins_ch1/cfm \& http://www.niri.org/about/origins_ch2.cfm

Murray, T. D. (2004, November 8). The masses move into markets: Investing is no longer a lifestyle of just the rich and famous. PR Newswire. Retrieved November 22, 2004.

National Investor Relations Institute (NIRI) 2011. Sarbanes-Oxley. Retrieved from: http://www.niri.org/Main-Menu-Category/advocate/regulations/Sarbanes-Oxley.aspx

National Investor relations Institute. About us. Retrieved March 29, 2011 from http://www.niri.org/FunctionalMenu/About.aspx

National Investor Relations Institute. (2003, March). Mission and goals. Retrieved May 1, 2007, from http://www.niri.org/about/mission.cfm

National Investor Relations Institute. (1985). Emerging trends in investor relations. Washington, DC: Author.

National Investor Relations Institute. (1989). Emerging trends in investor relations (2nd ed.). Washington, DC: Author.

O'Rourke. A. (2002). A new politics of engagement: shareholder activism for corporate social responsibility. INSEAD, Fontainebleau.

Pavlik, J. V (1987). Public relations: What research tells us. Beverly Hills: Sage. 
Petersen, B. K., \& Martin, H. J. (1996). CEO perceptions of investor relations as a public relations function: An exploratory study. Journal of Public Relations Research, 8(3),173-209.

Public Relations Society of America. (n.d.). Section guidelines. Retrieved January 31, 2009, from http://ww.prsa.org/networking/sections/fc/sectionGuidelines.html

Public Relations Society of America Task Force. (1988). Public relations body of knowledgetask force report. Public Relations Review, 14(1), 3-40.

Rao, H., \& Sivakumar, K. (1999). Institutional sources of boundary-spanning structures: The establishment of investor relations departments in the Fortune 500 industrials. Organizational Science, 10(1), 27-42.

Schoderbek, P. 1967. Management systems: A book of readings. New York: Wiley.

Schoderbek, P., Kefalas, A.G. and Schoderbek, C.G. (1975). Management systems: Conceptual considerations.

Silver, D. (2005). Creating transparency for public companies: The convergence of $P R$ and IR in the post Sarbanes-Oxley marketplace. Public Relations Strategist, 11(1), 14-17.

Silver, D. (2004). The IR-PR nexus. In B. F. Cole (Ed.), The new investor relations: Expert perspectives on the state of the art (pp. 59-88). Princeton, NJ: Bloomberg Press.

Skyttner, Lars. (2001) General Systems Theory: Ideas and Applications. NJ, USA: World Scientific, $\mathrm{p} 43$.

Sofres. N. (2001). European survey on socially responsible investment and the financial community. CSR Europe, Brussels.

Sorkin. R. A (2011). On Wall Street, a Protest Matures. New York Times.Retrieved from: http://dealbook.nytimes.com/2011/10/03/on-wall-street-a-protest-matures/

The World Bank. (2011). Listed domestic companies, total. Retrieved from: http://data.worldbank.org/indicator/CM.MKT.LDOM.NO/countries

The World Bank. (2011). Market capitalization of listed companies (current US\$). Retrieved from: http://data.worldbank.org/indicator/CM.MKT.LCAP.CD/countries

Tonello, M. (2006). Revisiting stock market short-termism. New York: The Conference Board.

Tuominen, P. (1997). Investor relations: A Nordic school approach. Corporate Communications, 2(1), 46-55.

US Social Investment Forum (2011). About us. Retrieved from: http://ussif.org/about/

US Social Investment Forum (2011). Socially responsible investment facts. Retrieved from: http://ussif.org/resources/sriguide/srifacts.cfm 
Watson. M. L, (2005). Illusions of trust: A comparison of corporate annual report, executive letters before and after SOX. Institute for Public Relations study.

Williams. H., (2000, November 3). Financial pr offers most direct route to the board marketing services giants are racing to acquire the diminishing number of independent financial $\mathrm{pr}$ specialists for that all-important boardroom access. PR Week, pp. 8.

Yuthas, K., Rogers, R., \& Dillard, J. F. (2002). Communicative action and corporate annual reports. Journal of Business Ethics, 41(1), 141-157.

Zhou. S., \& Sloan. D., (2009), Research methods in communication, 112-146. 


\section{Appendix A}

\section{Cover Letter}

1. WestVirginiaUniversity

Perley Isaac Reed School of Journalism

\section{Dear Investor Relations Professional:}

Your participation is sought for a research study to identify the desired expertise and educational backgrounds of entry-level Investor Relations employees. This study is part of an academic master's thesis that aims to enhance our understanding of entry-level IR practice and facilitate the development of appropriate curricula for future IR professionals. As a token of our appreciation for your time and consideration, we will gladly provide you with an executive summary of our results.

This project is conducted by co-investigator Deepa Fadnis, a graduate student in the P.I. Reed School of Journalism at West Virginia University, with the supervision of the principle investigator, Associate Professor Diana Martinelli, Ph.D. Your participation in this project is greatly appreciated and will take approximately 10 minutes to fill out the attached questionnaire, which is accessible through a separate link hosted by Survey Monkey towards the end of this letter.

West Virginia University's Institutional Review Board (IRB), which is charged with protecting study participants, has acknowledgment of this study on file and requires that I disclose the following information regarding your participation:

You must be 18 years or older to participate in this study and have at least six months' experience in IR. All responses will be kept as confidential as is legally possible. All data received will be reported in the aggregate, and you will not be asked any personal information that could identify you. Your participation is completely voluntary, and you may skip any question or discontinue the survey at any time without effect.

I hope that you will participate in this research project, as it could help us better understand the demands on entry-level IR professionals and how best to prepare them academically for this important field. Should you have any questions about this letter or study, please feel free to contact Dr. Diana Martinelli at 304-293-6561 or write to her at Diana.Martinelli@mail.wvu.edu.

Here is a link to the questionnaire:

We greatly appreciate your contribution.

Sincerely,

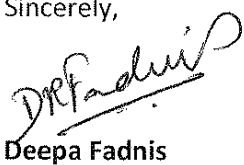

Co-Investigator and WVU master's candidate

Phone: 304-293-3505 1511 University Averue

Fax: 304-293-3072 PO Box 6010

journalism.wvi.edu/ Morgantown, WV 26506-6010 


\section{Appendix B}

Title: Investor Relations: A study of entry-level expertise and education

Email 1: Prior intimation (This email was sent a few days before the study's official protocol consent cover letter and survey link were emailed.)

Subject: Your experience with entry-level IR expertise and education

\section{Dear Investor Relations Professional:}

We seek your participation in an academic study being conducted at the P. I. Reed School of Journalism at West Virginia University to identify the expertise and educational backgrounds of entry-level employees in Investor Relations. Your participation will greatly benefit our understanding of entry-level IR practice and will help us to recommend and develop educational curricula for future IR professionals. As a token of our appreciation for your time and consideration, we will gladly provide you with an executive summary of our results.

In a few days, you will receive an email introducing you further to the study and its objectives. This correspondence will include a link to our brief, 10-minute survey, which is hosted by Survey Monkey. (Please feel free to forward it to other IR professionals as well.) Meanwhile, should you have any questions about this letter or the study, please feel free to contact the study's Principal Investigator, Dr. Diana Martinelli, at 304-293-6561 or write to her at Diana.Martinelli@mail.wvu.edu.

We greatly appreciate your consideration and hope you will contribute to our understanding of entry-level IR expectations and demands.

Sincerely,

Deepa Fadnis

Co-PI and WVU master's degree candidate 
Email 2: Formal protocol consent cover letter and the link to the survey (hosted by Survey Monkey).

Subject: Entry-level IR preparation study

Dear Investor Relations Professional:

I contacted you about a week ago regarding an important study that seeks to identify knowledge and skills critical for entry-level IR practitioners. Attached is a formal letter that details specifics about the study and includes a link to the study's survey. I have also copied and pasted the letter and link below, for your convenience. Please feel free to forward this survey to other IR professionals as well.

Your insights are very important to us, and we greatly appreciate your time and consideration.

Sincerely,

Deepa Fadnis

Co-PI and WVU master's degree candidate 


\section{Email 3: Reminder 1 sent one week after the formal letter was distributed}

Subject: Reminder: Entry-level IR Survey

\section{Dear Investor Relations Professional:}

If you have not yet participated in our brief survey, this is a gentle request to complete it at this time by reading the attached letter, which includes the survey link. (The letter and link also appear below for your convenience.) Your participation should take fewer than 10 minutes and will help us to better understand entry-level IR expertise and educational preparation and to recommend future curricula for students interested in this field.

If you've already completed the survey, we sincerely thank you for your time and contributions and ask that you forward this link to other Investor Relations professionals, so they might also participate in this study. In addition, if you would like to receive an executive summary of our findings, please reply to this email and include the following subject line: "Executive Summary Request".

Sincerely,

\section{Deepa Fadnis}

Co-PI and WVU master's degree candidate 


\section{Email 4: Reminder 2 sent two weeks after the formal letter was distributed}

Subject: Gentle Reminder: Entry-level IR Survey

\section{Dear Investor Relations Professional:}

A gentle reminder regarding our brief survey, which should take fewer than 10 minutes to complete and will help us to better understand entry-level IR expertise and educational preparation and to recommend future curricula for students interested in this field. If you have not already done so, please complete it now by reading the attached letter, which includes the survey link and which is also pasted below for your convenience.

If you've already completed the survey, we sincerely thank you for your time and contributions and ask that you forward this link to other Investor Relations professionals, so they might also participate in this study. In addition, if you would like to receive an executive summary of our findings, please reply to this email and include the following subject line: "Executive Summary Request".

Sincerely,

\section{Deepa Fadnis}

Co-PI and WVU master's degree candidate 


\section{Email 5: Reminder 3 sent three weeks after the formal letter was distributed}

Subject: Final Reminder: Entry-level IR Survey

\section{Dear Investor Relations Professional:}

A gentle, final reminder regarding our brief survey, which should take fewer than 10 minutes to complete and will help us to better understand entry-level IR expertise and educational preparation and to recommend future curricula for students interested in this field. If you have not already done so, please complete it now by reading the attached letter, which includes the survey link and which is also pasted below for your convenience.

If you've already completed the survey, we sincerely thank you for your time and contributions and ask that you forward this link to other Investor Relations professionals, so they might also participate in this study. In addition, if you would like to receive an executive summary of our findings, please reply to this email and include the following subject line: "Executive Summary Request".

Sincerely,

Deepa Fadnis

Co-PI and WVU master's degree candidate 


\section{Appendix C}

\section{Web Based Survey of Investor Relations practice}

Industry: Job title:

1. When screening applicants for entry-level positions in your IR department/agency, what skills does your company look specifically for? (Please check all that apply.)

- Writing skills

- Verbal communication skills

- Financial understanding

- Accounting skills

- Sales and marketing skills

- Legal knowledge

- Don't know/not sure

- Other (please specify)

2. Who are the external stakeholders your organization's entry-level IR practitioners interact with most frequently? (Please check all that apply.)

- Private investors

- Institutional investors, funds, and similar

- Stock analysts, brokers, and similar

- Stock exchanges, trading systems, and similar

- Government and other regulatory organizations

- Activist and advocacy groups

- Market surveillance providers

- Mass media and similar

- Other (please specify)

- Not applicable

3. Who are the internal stakeholders your organization's entry-level IR practitioners interact with most frequently? (Please check all that apply.)

- Management

- Internal shareholders

- Communications department

- Finance department

- Legal department

- Employees

- Others (please specify)

- Not applicable 
4. What tasks are entry-level IR practitioners in your department/agency expected to perform? (Please check all that apply.)

- Report preparations (annual reports or other shareholder reports)

- Collecting data for ownership research

- Mass media communications (advertising, editorials, etc.)

- Securities placements (IPO, private placements, etc.)

- One-on-one meetings, negotiations.

- Roadshows, presentations, conferences, etc.

- Responding to requests from shareholders, analysts, stockbrokers, etc.

- Providing information to top management or other departments of the organization

- Compliance with regulations and policies

- Management tasks

- Other (please specify)

- Not applicable

5. Do you have in-house training sessions for entry-level IR staff?

- Yes

- No

- Don't know/Not sure

6. In your opinion, what academic coursework should an applicant have to be considered for an entry-level IR position in your department/agency? (Please check all that apply.)

- Business

- Finance

- Communications

- Public Relations

- Marketing

- Other (please specify) 
7. In your opinion, what skills are new entrants in the IR field most often lacking? (Please check all that apply.)

- Writing skills

- Verbal communications skills

- Financial understanding

- Accounting skills

- Legal knowledge

- Nothing

- Don't know/not sure

- Others (please specify)

8. Please specify your years of investor relations experience:

- Less than 1 year

- $1-5$ years

- $6-10$ years

- More than 10 years

9. Which of the following describes your formal educational background? (Please check all that apply.)

- Finance

- Business

- Marketing

- Communication

- Public Relations

- Journalism

- Political Science

- History

- None of the above

- Others (please specify)

10. What specific types of courses do you believe students should take for a career in investor relations?

Thank you for taking this survey. Your participation is highly valued. 


\section{Appendix D}

Based on the findings of the survey, here is a list of essential tasks performed and academic coursework required at the entry-level in the field of investor relations.

\section{Tasks}

1. Collecting data for ownership research

2. Responding to requests from stakeholders and stockholders

3. Providing information to top management or other departments of the organization

4. Roadshows, presentations, conferences, etc

5. One-on-one meetings, negotiations

6. Management tasks

7. Compliance with regulations and policies

8. Mass media communications (advertising, editorials, etc)

9. Securities placements (IPO, private placements, etc.)

10. Miscellaneous
a. Collate investor information
b. Coordinate press releases
c. Collecting data for management communications

\section{Academic Coursework}

Coursework in the order of preference in the IR industry (based on survey findings)

1. Finance

2. Business

3. Communications

4. Marketing

5. Public Relations 
6. Others: Understanding of financial statements, industry specific, media production, political science

Academic course groupings based on survey results (course groups derived from undergraduate and graduate West Virginia University course catalogue):

Finance: accounting, financial statement analysis, corporate finance, regulatory finance, and valuation

Business: Economics, macroeconomics, marketing, markets, and business development

Communications: Writing skills, presentation skills, media management training, journalism, public relations, corporate communications, and basics of advertising and graphic design.

Social Sciences: Philosophy, political science and history

Languages: English, French and Spanish

Legal: Business law and securities law

Industry-specific courses: Pharmaceutical, technology, information technology, banking, consumer products and retail 